\title{
DNA FISH Diagnostic Assay on Cytological Samples of Thyroid Follicular Neoplasms ${ }^{\dagger}$
}

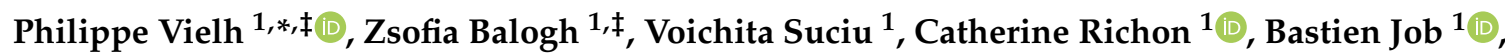 \\ Guillaume Meurice ${ }^{1}$, Alexander Valent ${ }^{1}$, Ludovic Lacroix ${ }^{1}$, Virginie Marty ${ }^{1}$, Nelly Motte ${ }^{1, \S}$, \\ Philippe Dessen 1 ${ }^{(D)}$, Bernard Caillou 1,ll, Abir Al Ghuzlan 1, Jean-Michel Bidart 1,§, \\ Vladimir Lazar ${ }^{1} \S$, Paul Hofman ${ }^{2}$ (D) Jean-Yves Scoazec ${ }^{1}$, Adel K. El-Naggar ${ }^{3, \ddagger}$ and \\ Martin Schlumberger $4, \ddagger$
}

1 Department of Medical Biology and Pathology, Gustave Roussy, Université Paris-Saclay and Experimental and Translational Pathology Platform, CNRS UMS3655-INSERM US23 AMMICA, 94805 Villejuif, France; zsofia.balogh@gustaveroussy.fr (Z.B.); voichita.suciu@gustaveroussy.fr (V.S.); catherine.richon@gustaveroussy.fr (C.R.); bastien.job@gustaveroussy.fr (B.J.); guillaume.meurice@gustaveroussy.fr (G.M.); alexander.valent@gustaveroussy.fr (A.V.); ludovic.lacroix@gustaveroussy.fr (L.L.); virginie.marty@gustaveroussy.fr (V.M.); philippe.dessen@gustaveroussy.fr (P.D.); abir.alghuzlan@gustaveroussy.fr (A.A.G.); jean-yves.scoazec@gustaveroussy.fr (J.-Y.S.)

2 Laboratory of Clinical and Experimental Pathology and Biobank, Pasteur Hospital, 06002 Nice, France; hofman.p@chu-nice.fr

3 Department of Pathology, The University of Texas MD Anderson Cancer Center, Houston, TX 77030, USA; anaggar@mdanderson.org

4 Department of Endocrinology, Gustave Roussy, Université Paris-Saclay, 94805 Villejuif, France; martin.schlumberger@gustaveroussy.fr

* Correspondence: ph.vielh@outlook.com or p.vielh@medipath.fr

+ This work was presented in part at the 106th Annual Meeting of the United States \& Canadian Academy of Pathology, San Antonio, TX, USA, 4-10 March 2017.

$\ddagger$ These authors contributed equally to this work.

$\S$ These authors are retired.

\| Deceased. This work is dedicated to Bernard Caillou, Pathologist.

Received: 20 July 2020; Accepted: 2 September 2020; Published: 6 September 2020

check for updates

Simple Summary: Cytopathology cannot distinguish benign from malignant follicular lesions in $20-30 \%$ of cases. These indeterminate cases includes the so-called follicular neoplasms (FNs) according to The Bethesda System for Reporting Thyroid Cytopathology. Frozen samples from 66 classic follicular adenomas (cFAs) and carcinomas (cFTCs) studied by array-comparative genomic hybridization identified three specific alterations of cFTCs (losses of 1p36.33-35.1 and 22q13.2-13.31, and gain of whole chromosome X) confirmed by fluorescent in situ hybridization (FISH) in a second independent series of 60 touch preparations from frozen samples of cFAs and cFTCs. In a third independent set of 27 cases of already stained pre-operative fine-needle aspiration cytology samples diagnosed as FNs and histologically verified, FISH analysis using these three markers identified half of cFTCs. Specificity of our assay for identifying cFTCs is higher than $98 \%$ which might be comparable with $B R A F^{600 \mathrm{E}}$ testing in cases of suspicion of classic papillary thyroid carcinomas.

Abstract: Although fine-needle aspiration cytology (FNAC) is helpful in determining whether thyroid nodules are benign or malignant, this distinction remains a cytological challenge in follicular neoplasms. Identification of genomic alterations in cytological specimens with direct and routine techniques would therefore have great clinical value. A series of 153 cases consisting of 72 and 81 histopathologically confirmed classic follicular adenomas (cFAs) and classic follicular thyroid carcinomas (cFTCs), respectively, was studied by means of different molecular techniques in three different cohorts of patients (pts). In the first cohort (training set) of 66 pts, three specific alterations 
characterized by array comparative genomic hybridization (aCGH) were exclusively found in half of cFTCs. These structural abnormalities corresponded to losses of 1p36.33-35.1 and 22q13.2-13.31, and gain of whole chromosome $X$. The second independent cohort (validation set) of 60 pts confirmed these data on touch preparations of frozen follicular neoplasms by triple DNA fluorescent in situ hybridization using selected commercially available probes. The third cohort, consisting of 27 archived cytological samples from an equal number of pts that had been obtained for preoperative FNAC and morphologically classified as and histologically verified to be follicular neoplasms, confirmed our previous findings and showed the feasibility of the DNA FISH (DNA fluorescent in situ hybridization) assay. All together, these data suggest that our triple DNA FISH diagnostic assay may detect $50 \%$ of cFTCs with a specificity higher than $98 \%$ and be useful as a low-cost adjunct to cytomorphology to help further classify follicular neoplasms on already routinely stained cytological specimens.

Keywords: thyroid; fine-needle aspiration; indeterminate cytology; follicular neoplasms; array comparative genomic hybridization; fluorescent in situ hybridization

\section{Introduction}

Thyroid nodules are a frequent finding, as they are palpable in approximately $5-10 \%$ of adults and detectable in $50-70 \%$ of people over the age of 60 by means of ultrasonography (US) [1-3]. However, malignant nodules are rare (5-10\%), and the prognosis of patients with well-differentiated carcinomas is usually equally excellent for both sexes [4-9]. The triage of patients who are the best candidates for an initial surgical treatment based on evidence-based strategies is therefore needed to accurately identify preoperatively malignant thyroid nodules $[1,10]$.

The most reliable initial diagnostic tool for the evaluation of thyroid nodules is the cytomorphologic study of materials obtained by fine-needle aspiration cytology (FNAC), preferentially guided by US [1] and reported according to The Bethesda System for Reporting Thyroid Cytopathology (TBSRTC) [11,12]. In $70-80 \%$ of all cases, FNAC provides a definitive diagnosis of benign lesions or papillary thyroid cancer (PTC) [1]. However, a meta-analysis published in 2012 reported that cytopathology alone cannot reliably distinguish benign from malignant follicular lesions in $20-30 \%$ of cases [13]. Such cases correspond to one of the three following TBSRTC indeterminate categories, the so-called "gray zone": atypia or follicular lesion of undetermined significance (AUS/FLUS: category III), follicular or suspicious for a follicular neoplasm (FN/SFN: category IV) and suspicious for malignancy (SM: category V), the latter being mainly suspicious for PTC [11,12]. In addition to the difficulty in segregating follicular neoplasms into classic follicular adenoma ( $\mathrm{cFA}$ ) and malignant lesions, such as classic follicular thyroid carcinoma (cFTC), encapsulated follicular variant of papillary carcinoma (eFVPTC) and infiltrative follicular variant of papillary carcinoma (iFVPTC) [11], recognizing the recent entity known as noninvasive follicular tumor with papillary-like nuclear features (NIFTP) is even more challenging $[12,14,15]$. This is largely due to the current reliance on the established architectural criteria for histopathological examination of the surgical specimen [16].

Since FNAC has limitations in providing a definitive diagnosis for some nodules, management of the corresponding patients is hampered. For example, surgery may be unnecessary in cases of benign disease or suboptimal for patients with thyroid cancer who will need a second completion surgery. Consequently, identification of additional criteria to refine the use of FNAC for the diagnosis of thyroid malignancy has received considerable attention in recent years as a part of efforts to optimize medical and surgical management of patients, to minimize overtreatment and to reduce unnecessary surgeries along with their subsequent risks and health care burden [17-19].

In 2014, The Cancer Genome Atlas (TCGA) research network identified and reported recurrent gene mutations and fusions in PTC [20]. Tumors with true papillary structure were dominated by $B R A F^{\mathrm{V} 600 \mathrm{E}}$ mutations and $R E T$ kinase fusions and were designated as being $B R A F^{\mathrm{V} 600 \mathrm{E}}$-like, whereas 
iFVPTCs were conversely dominated by RAS mutations and were designated as being RAS-like [21]. This was later confirmed by an independent study [22]. However, few somatic molecular abnormalities have been shown to be diagnostically useful $[23,24]$. The best example is the BRAF ${ }^{\mathrm{V} 600 \mathrm{E}}$ mutation observed in approximately half of classic PTCs (cPTCs), in a higher percentage of the tall cell and hobnail PTC variants, and in FVPTCs. However, $B R A F^{\mathrm{V} 600 \mathrm{E}}$ mutation is virtually not present in cFTCs [25]. Similarly, gene fusions between RET and different PTC partners in PTCs, including the RET/PTC3 rearrangement which is more common in radiation-induced thyroid cancer [26], are not observed in cFTCs. In addition, the large spectrum of follicular-pattern benign and malignant tumors that share common genetic alterations is striking. For example, cFA, cFTC, NIFTP, eFVPTC, iFVPTC, cPTC and Hürthle cell carcinoma (HCC) may carry RAS point mutations, and all except for eFVPTC may carry DICER1 alterations [25]; the PPAR $\gamma$-PAX8 gene fusion may be observed in cFA, cFTC and FVPTC as well as the THADA gene fusion in cFA, cFTC and NIFTP [25].

Known driver mutations in cFTCs correspond mainly to: (i) point mutations of the three human RAS genes (NRAS, HRAS and KRAS by frequency order) at codons 61 and, less frequently, at codons 12 or 13 in close to half of all cases. Other gene mutations may occur in PTEN, DICER1, EIF1AX (10-15\%, each), PIK3CA (5-10\%), IDH1 and IDH2 (<5\% each), with BRAF ${ }^{\mathrm{K} 601}$ mutations being rare; (ii) large-scale alterations also occur, such as PAX8-PPAR $\gamma(10-20 \%)$ and THADA-IGF2BP3 (<5\%) gene fusions [27]. Here, again, most genetic alterations, including PIK3CA and PTEN mutations and PPAR $\gamma$ fusions with other partners, such as CREB3L2, may also be observed in some cases of cFA, FVPTC, NIFTP and Hürthle (oncocytic) cell neoplasms [27], precluding their use in a diagnostic test [28].

Although traditionally considered variants of follicular neoplasms, Hürthle cell neoplasms now represent a different entity according to the 2017 WHO classification of tumors of endocrine organs [16], with a distinct pathogenesis and clinical behavior [29-32]. They were not included in our study, even though cytomorphology is usually able to detect these tumors [33-36]. Similarly to the differential diagnosis between cFA and cFTC, demonstration of capsular and/or vascular invasion is required to ascertain malignancy [37-41].

Our hypothesis was that an in-depth analysis of a large series of cFA and cFTC genetic landscapes could potentially help to identify a combination of large-scale alterations, such as somatic copy number variations (sCNVs) characteristic of $\mathrm{cFTC}$, and that these novel and validated genetic biomarkers would be critical for developing simple and direct tests that are applicable to cytological specimens to complement cytomorphology. Thus, we first studied two independent (training and validation) sets of histologically confirmed samples from two comprehensive cancer centers (Gustave Roussy (GR), Villejuif, France, and the University of Texas MD Anderson Cancer Center (UT MDACC), Houston, TX, USA): these two sets were frozen tissues from 126 pts with cFA $(n=59)$ and cFTC $(n=67)$. A third set comprising 27 stained FNAC smears (27 pts), morphologically preoperatively classified as FN/SFN according to TBSRTC and then histologically verified on the corresponding postoperative surgical specimens, represented the feasibility set.

\section{Materials and Methods}

\subsection{Study Design, Patients and Tissue Sample Characterization}

Figure 1 shows the flow chart of the study. All patients provided oral informed consent for the use of their samples. The institutional ethics and review board committees of GR and UT MDACC (respectively, \#RT0106 and \#DR11-0348 and MTA \#2011-8521, approval date: 1 May 2020) approved this study. All frozen histological sections and touch preparations were verified by senior pathologists (Bernard Caillou and Philippe Vielh), and these materials showed that the tumor cell content was at least $80 \%$. The initial diagnosis of cFTC performed on paraffin-embedded histopathological samples according to the $2004 \mathrm{WHO}$ classification [37] was kept (invasion of the capsule only representing minimally invasive cFTC as opposed to widely invasive cFTC). These initial diagnoses were not 
retrospectively reclassified and stratified according to the most recent 2017 WHO classification of tumors of endocrine organs [16] and the number of veins ( $<4 \mathrm{vs.} \geq 4)$ invaded [38].

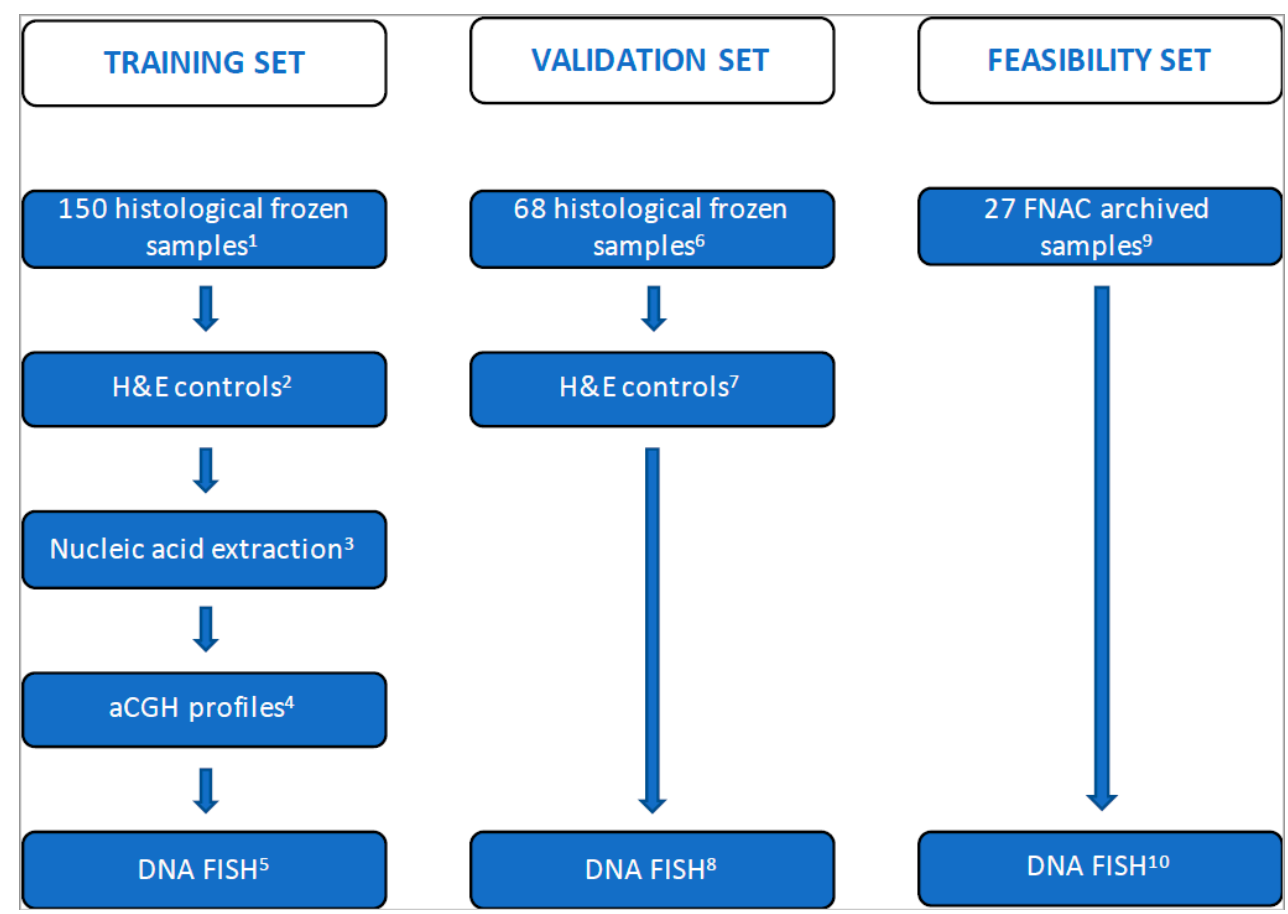

Figure 1. Flow chart of the study. Abbreviations: pts: patients; H\&E: hematoxylin \& eosin; aCGH: array comparative genomic hybridization; DNA FISH: DNA fluorescent in situ hybridization; hyb: hybridization; FNAC: fine needle aspiration cytology. Training set: ${ }^{1}$ from 87 pts; ${ }^{2}$ from 69 pts (after exclusion of 18 cases: 10 atypical adenomas, four oxyphilic neoplasms, two uncertain diagnoses, one follicular variant of papillary carcinoma, one non-tumoral); ${ }^{3}$ from $67 \mathrm{pts}$ (after exclusion of two cases with insufficient DNA for analysis); ${ }^{4}$ from 66 pts (after exclusion of one case with doubtful aCGH result); ${ }^{5}$ from 44 pts (with available residual tissue). Validation set: ${ }^{6}$ from 68 pts; ${ }^{7}$ from 60 pts (after exclusion of eight cases: six oxyphilic neoplasms, one atypical adenoma, one metastatic tumor); ${ }^{8}$ from 60 pts. Feasibility set: ${ }^{9}$ from 27 pts (preoperative routinely stained FNAC with histological assessment of the corresponding postoperative tissue); ${ }^{10}$ from 27 pts.

As shown in Figure 1, the study comprised three cohorts representing the training, validation and feasibility sets. The first cohort (training set) to be analyzed by aCGH consisted of 150 snap-frozen tumor and matched normal tissue samples, whenever possible (see also the first paragraph from Section 2.4.) from 87 pts. After exclusion of 21 cases (Figure 1), the training set consisted of 66 cases of follicular neoplasms corresponding to 33 cFAs and 33 cFTCs (Table 1). Of these 66 cases, 44 with follicular neoplasms underwent further DNA FISH analysis of touch preparations from frozen tissues (Figure 1). The second cohort (validation set) consisted of 68 samples (68 pts) corresponding to 26 cFAs and 34 cFTCs (Table 1) from 60 pts studied by DNA FISH on touch preparations from the corresponding frozen tissues. The third cohort (feasibility set) consisted of a series of 27 archived preoperative thyroid FNAC specimens (Figure 1), reported as FN/SFN by cytology according to TBSRTC [11]. Histopathological examination of the corresponding postresection surgical specimens, paired with those of the training and validation sets, showed cFTC and cFA in 14 and 13 cases, respectively. Cases with at least two cytology slides available (to maintain one in the archives for medico-legal purposes) were retrieved, and one was further used for DNA FISH. 
Table 1. Clinicopathological and biological characteristics of the 126 patients with follicular thyroid neoplasms (training and validation sets).

\begin{tabular}{|c|c|c|c|c|c|c|c|c|c|c|}
\hline \multirow{2}{*}{ Characteristics } & \multirow{2}{*}{ Unit } & \multicolumn{3}{|c|}{ Training Set } & \multicolumn{3}{|c|}{ Validation Set } & \multicolumn{3}{|c|}{ Total } \\
\hline & & Adenoma & Carcinoma & Total & Adenoma & Carcinoma & Total & Adenoma & Carcinoma & Total \\
\hline Patients & Number & $33(50 \%)$ & $33(50 \%)$ & $66(100 \%)$ & $26(43 \%)$ & 34 (57\%) & $60(100 \%)$ & $59(47 \%)$ & $67(53 \%)$ & $126(100 \%)$ \\
\hline Gender: & Number & & & & & & & & & \\
\hline Female & & $21(64 \%)$ & $16(48 \%)$ & 37 (56\%) & $20(77 \%)$ & $20(59 \%)$ & $40(67 \%)$ & $41(69 \%)$ & $36(54 \%)$ & 77 (61\%) \\
\hline Male & & $12(36 \%)$ & $17(52 \%)$ & $29(44 \%)$ & $6(23 \%)$ & $14(41 \%)$ & $20(33 \%)$ & $18(31 \%)$ & $31(46 \%)$ & $49(39 \%)$ \\
\hline Age med. (range) & Years & $52(21-70)$ & $53(25-78)$ & $52(21-78)$ & $47(27-75)$ & $54(21-82)$ & $51(21-82)$ & $50(21-75)$ & $53(21-82)$ & $52(21-82)$ \\
\hline $\mathrm{T}$ size med. (range) & $\mathrm{cm}$ & $3(1-6.4)$ & $4.5(1-15)$ & $3.8(1-15)$ & $2.8(1.5-9)$ & $4.4(1.5-11)$ & $3.7(1.5-11)$ & $2.9(1-9)$ & $4.5(1-15)$ & $3.7(1-15)$ \\
\hline $\begin{array}{l}\text { Follow-up med. } \\
\text { (range) }\end{array}$ & Months & $35(3-180)$ & $47(0-140)$ & $41(0-180)$ & $12(1-48)$ & $42(2-120)$ & $29(1-120)$ & $25(1-180)$ & $44(0-140)$ & $35(0-180)$ \\
\hline Clinical status & $\begin{array}{l}\text { Number, } \\
\text { alive }\end{array}$ & $32(100 \%)$ & $30(91 \%)$ & $62(95 \%)$ & $26(100 \%)$ & $30(88 \%)$ & $56(93 \%)$ & $58(100 \%)$ & $60(90 \%)$ & $118(94 \%)$ \\
\hline \multicolumn{11}{|c|}{ Mutations: } \\
\hline$K R A S / \mathrm{N}$ & & $0(0 \%) / 1$ & $0(0 \%) / 1$ & - & $1(5 \%) / 4$ & $0(0 \%) / 5$ & - & $1(2 \%) / 5$ & $0(0 \%) / 6$ & - \\
\hline$H R A S / \mathrm{\Lambda}$ & & $1(3 \%) / 1$ & $5(16 \%) / 2$ & - & $1(4 \%) / 2$ & $6(20 \%) / 4$ & - & $2(4 \%) / 3$ & $11(18 \%) / 6$ & - \\
\hline$N R A S / \mathrm{\Lambda}$ & & $2(6 \%) / 1$ & $6(20 \%) / 3$ & - & $4(17 \%) / 2$ & $8(27 \%) / 4$ & - & $6(11 \%) / 3$ & $14(23 \%) / 7$ & - \\
\hline$B R A F / \mathrm{N}$ & & $0(0 \%) / 1$ & $1(3 \%) / 1$ & - & $0(0 \%) / 2$ & $0(0 \%) / 4$ & - & $0(0 \%) / 3$ & $1(2 \%) / 6$ & - \\
\hline CTNNB1/ & & $0(0 \%) / 1$ & $0(0 \%) / 1$ & - & - & - & - & $0(0 \%) / 1$ & $0(0 \%) / 1$ & - \\
\hline PIK3CA/I & & $0(0 \%) / 1$ & $0(0 \%) / 3$ & - & - & - & - & $0(0 \%) / 1$ & $0(0 \%) / 3$ & - \\
\hline \multicolumn{11}{|c|}{ Translocations: } \\
\hline PAX8/PPAR & NA & $0(0 \%) / 1$ & $3(12 \%) / 7$ & - & $0(0 \%) / 2$ & $2(6 \%) / 1$ & - & $0(0 \%) / 3$ & $5(8 \%) / 8$ & - \\
\hline RET/PTC1 & & $0(0 \%) / 0$ & $0(0 \%) / 7$ & - & $0(0 \%) / 0$ & $0(0 \%) / 0$ & - & $0(0 \%) / 0$ & $0(0 \%) / 7$ & - \\
\hline
\end{tabular}


Table 1 summarizes the clinicopathological characteristics of the 126 follicular neoplasms studied in the training and validation sets. DNA ploidy analysis was performed whenever possible, as well as mutational analysis of the RAS family of genes, CTNNB1 and PIK3CA genes by Sanger direct sequencing, and translocation analysis (PAX8/PPAR $\gamma$ and RET/PTC1) by reverse-transcriptase-polymerase chain reaction (RT-PCR).

\subsection{DNA Ploidy Analysis}

Frozen tumor tissue samples were quickly thawed and dissociated mechanically, and the DNA was stained with the BD CycleTEST PLUS DNA Reagent Kit (Beckton Dickinson, San Jose, CA, USA). DNA flow cytometry was performed on a Beckman Coulter Epics XL MCL flow cytometer equipped with a 488-nm argon laser (Beckman Coulter, Villepinte, France). The DNA diploid peak was located on DNA histograms according to an external standardization procedure using normal human lymphocytes. When a slight DNA abnormality was suspected, thawed normal human lymphocytes were added to the cell suspensions before DNA staining. The resulting DNA histograms were interpreted using MultiCycle AV software (Phoenix Flow Systems, San Diego, CA, USA). DNA indices (DIs) were computed as previously described [42]. DIs ranging from 0.9 to 1.1 corresponded to DNA diploidy; DIs between 0.6 and 0.9 and between 1.1 and 1.8 were classified as DNA aneuploid; DIs between 0.5 and 0.6 and between 1.8 and 2.2 were considered DNA haploid and DNA tetraploid, respectively. DNA multiploidy corresponded to cases with the presence of two or more DIs.

\subsection{Nucleic Acid Extraction}

DNA was extracted from paired frozen normal and tumor samples using the DNeasy ${ }^{\circledR}$ Tissue Kit (Qiagen, Hilden, Germany) according to the manufacturer's recommendations.

RNA extraction was performed using the TRIzol ${ }^{\circledR}$ Reagent Protocol (Invitrogen, Carlsbad, CA, USA). Total RNA was quantified, and the purity was assessed using a Nanodrop ND-1000 spectrometer and a Bioanalyser-2100 (Agilent, Santa Clara, CA, USA).

\subsection{Oligonucleotide aCGH Assay, Data Processing and Analysis}

In $53(80 \%)$ out of 66 cases (training set), the matched normal tissue sample was used as a reference for comparison with the corresponding tumor sample. For the remaining $13(20 \%)$ cases in which no normal tissue was available, commercially available pooled sex-matched Human Genomic DNA (Promega, Madison, WI, USA) was used as the reference sample (see also Section 2.1 about study design in Materials and Methods).

Equal amounts (500 ng) of DNA from the tumor and normal samples were treated with the AluI and Rsal restriction enzymes (Fermentas, Euromedex, France) and labeled with cyanine (Cy)3-deoxyuridine triphosphate (dUTP) or Cy5-dUTP. Hybridization was carried out using Agilent 244K Whole Human Genome (G4411B) arrays (Agilent Technologies, Santa Clara, CA, USA) for $40 \mathrm{~h}$ at $65^{\circ} \mathrm{C}$ in a rotating oven (Robbins Scientific, Mountain View, CA, USA) at $20 \mathrm{rpm}$. Hybridization was followed by the appropriate washing steps. Scanning was performed with an Agilent G2505C DNA Microarray scanner at $100 \%$ PMT with $5 \mu \mathrm{m}$ resolution at $20^{\circ} \mathrm{C}$ in a low ozone concentration environment. Quantitation of the $\mathrm{Cy} 5$ and $\mathrm{Cy} 3$ signals from the scans was performed with Feature Extraction v10.1 (Agilent) using the default parameters.

Raw aCGH signals and $\log 2$ (ratio) profiles were normalized and centered using an as-yet unpublished in-house method according to the dye composition (Cy5/Cy3) and local GC\% composition. These profiles were segmented with the circular binary segmentation algorithm [43] through its implementation in the DNAcopy v1.30 package for R v2.15.1 using default parameters. DNA copy number imbalances were detected by considering a minimum of three consecutive probes and a minimal absolute amplitude threshold that was specific for each profile according to its internal noise. This specific internal noise was computed as one-fourth of the median of the absolute $\log 2$ (ratio) distances across consecutive probes on the genome. All aCGH coordinates in this study were 
mapped against the human genome as defined by the UCSC build hg19 (http://genome-euro.ucsc.edu/). Hierarchical clustering of samples was performed on segmented profiles using Pearson or Euclidean distance for whole-genome profiles or for selected genomic regions, respectively. Ward's method was used in both cases. Differential analysis was performed using Wilcoxon's sum-rank test and minimum differentiating were selected using an iterative approach: significant regions were filtered to keep regions for which all cFA samples were normal, then ranked by their increasing raw $p$-value; the significant region with the highest coverage of cFA was selected, then the next region covering the most new cFA samples not included in the first one, and so on. Frequency plots, clustering and heatmaps were all generated using $\mathrm{R}$ with in-house scripts. All statistical computations were performed using $\mathrm{R}$ with default packages. Genomic region annotation was performed by an in-house script using annotation resources available at the UCSC Tables repository (https://genome.ucsc.edu/cgi-bin/hgTables). Data are available under the Array Express accession number E-MTAB-1575.

\subsection{Triple DNA FISH Assay}

DNA FISH was performed on touch preparations of frozen tissues from 44 samples (training set, $44 \mathrm{pts}$ ) and 60 samples (validation set, 60 pts) and in a series of 27 (feasibility set, 27 pts) archived FNAC samples (Figure 1) with three commercially available directly labeled fluorescent probes (Vysis CEP X/Y, LSI TUPLE 1/LSI ARSA, Abbott Laboratories, Abbott Park, IL, USA; ZytoLight 1p36/1q25, ZytoVision, Bremerhaven, Germany): we named this combination the "Triple DNA FISH assay".

On touch preparations, cells were fixed directly with a 9:1 mixture of methanol and acetic acid for $15 \mathrm{~min}$ and air-dried overnight. After enzymatic pepsin treatment, nuclear DNA was denatured in $70 \%$ formamide/ $2 \times$ SSC and dehydrated. The probes were heated for $5 \mathrm{~min}$ at $85^{\circ} \mathrm{C}$ and hybridized overnight at $40^{\circ} \mathrm{C}$. Slides were washed with stringent buffer, air-dried and counterstained with DAPI.

On archived FNAC samples already stained using the May-Grünwald-Giemsa or Diff Quik methods, a slightly modified protocol was used. Briefly, coverslips were first removed using xylene, and cells were exposed to pepsin and dehydrated. Then, heat-denaturation was performed for $5 \mathrm{~min}$ at $80^{\circ} \mathrm{C}$. The glass slide was splitted in three different fields using small round coverslips and hybridization was carried out overnight at $40^{\circ} \mathrm{C}$. These archived FNAC samples were initially used for preoperative diagnostic purposes and then stored for a period of time ranging from 1 month up to 12 years. They corresponded to samples classified as FN/SFN according to TBSRTC (Bethesda category IV) $[11,12]$ and to cFA or cFTC on the matching histological specimens.

The triple DNA FISH assay was interpreted by senior cytogeneticists (Alexander Valent, Zsofia Balogh) blinded to histopathological results. Preparations were observed with an epifluorescence microscope (Leica Biosystems, Nanterre, France), and images were captured with the CytoVision imaging station (Leica Biosystems, France). Only nuclei with unambiguous probe hybridization were scored to determine the number of signals per nucleus. At least 100 nuclei were analyzed for each hybridization.

\subsection{Gene Mutation Analyses}

Exons 2 and 3 of KRAS (NM_033360.2), HRAS (NM_005343.2) and NRAS (NM_005343.2), exons 11 and 15 of BRAF (NM_004333.4), exon 3 of CTNNB1 (NM_001098209.1) and exons 1 and 21 of PIK3CA (NM_006218.2) were analyzed by direct Sanger sequencing after specific amplification by PCR, as previously described [44]. Sense and antisense sequences were screened for exonic alterations using SeqScape v2.5 software (Applied Biosystems, Foster City, CA, USA). All detected mutations were confirmed by at least one independent PCR.

\subsection{Translocation Analyses}

Total RNA (500 ng) was reverse-transcribed using Moloney murine leukemia virus reverse transcriptase in the presence of random primers (Applied Biosystems). Amplification of the RPLP0 housekeeping gene by quantitative real-time PCR was used as a control for the efficiency of the reverse 
transcription reaction. For each experiment, cDNA from samples known to be positive or negative for translocations was used as a control. PAX8-PPAR $\gamma 1$ and RET-PTC1 translocation detection assays were performed as previously described $[45,46]$.

\section{Results}

\subsection{Clinical, Histopathological and Biological Data}

The clinicopathological and biological characteristics of the 126 pts included in the training (66 pts) and validation (60 pts) sets are summarized in Table 1 . Histopathological subtypes [16] of cFA $(n=59)$ showed a microfollicular, macrofollicular and mixed architectural pattern of growth in 19, 13 and 27 pts, respectively (without fetal/solid type), whereas cFTCs $(n=67)$ with various growth patterns were minimally invasive (capsular invasion only) and widely invasive in 24 and 33 pts, respectively.

DNA flow cytometry was performed in the training and validation sets. As a whole, 37 (63\%) out of $59 \mathrm{cFAs}$ and 30 (58\%) out of 52 cFTCs (15 of which were unsatisfactory for interpretation) were DNA diploid tumors. The other cFAs were DNA aneuploid, tetraploid and multiploid tumors in 10 (17\%), four $(7 \%)$ and eight (13\%) cases, respectively (none were DNA haploid). The remaining cFTCs were DNA aneuploid, tetraploid and multiploid in 10 (19\%), four (7\%) and five (10\%) cases, respectively, while three $(6 \%)$ cases were DNA haploid.

There were no statistically significant differences $(p<0.05)$ in the clinical or biological data between the training with validation set. The only exception was that the $17 \mathrm{q}$ gain was more frequent in men and in cases with mutated genes of the RAS family $(p<0.05)$. One BRAF-mutated case was found in the training set.

\subsection{Training Set on Frozen Tissue}

By means of aCGH, sCNV was determined in a total of tumors from 66 pts (training set). Copy number gains were generally more frequent than losses, regardless of the tumor histological subtype, namely, minimally invasive (capsular invasion only) or widely invasive FTC. Figure 2A shows the global heatmap of the 66 clustered samples using the Pearson distance and Ward's construction method. Three subgroups were observed (Figure 2A): one with complex abnormalities found in 17 (26\%) out of 66 cases $(13(39 \%)$ out of 33 cFTCs and four (12\%) out of 33 cFAs; one with a single loss of $22 q$ found in a subpopulation of cFTCs (six (18\%) out of 33 cases) and no cFAs; and one with no recurrent structural genetic anomalies, comprising 29 (88\%) out of 33 cFAs and 14 (42\%) out of 33 cFTCs. Figure $2 \mathrm{~B}$ shows that the gains and losses for each chromosomal region were higher in CFTC than in cFA. Alterations found in both benign and malignant samples were gains of chromosomes 5, 7, 9, 12, 14, 16, 17 and 20 and losses of chromosomes 3, 4, 8, 11 and 21 (Figure 2B). No significant differences in terms of number or type of genomic anomalies were observed between minimally and widely invasive cFTCs. The heatmaps of the three discriminating chromosome arms/chromosomes (chromosomes 1p, 22q and $\mathrm{X}$ ) displayed two clusters (Figure 3). The first cluster contained 18 (55\%) out of $33 \mathrm{cFTCs}$ and one (3\%) out of 33 cFAs, and consisted of deletions of chromosome 1p or 22q and/or a gain of chromosome $X$. The second cluster included 32 (97\%) out of 33 cFAs and $15(45 \%)$ out of 33 cFTCs and exhibited no recurrent structural genetic abnormality or a gain of chromosome 22 as a distinguishing finding. Further analysis revealed that the three distinctive minimal common regions differentiating cFTCs from cFAs (Figure 4) were loss of 1p36.33-1p35.1 (five cases, 15\%); loss of 22q13.2-22q13.31 (eight cases, $24 \%$ ); and gain of chromosome X (eight cases, $24 \%$ ). In the training set, we found 21 genetic alterations in 18 pts (one case had two aberrations: 1p loss plus 22q loss; one case had all three aberrations: $1 p$ and $22 q$ losses and $X$ gain) (Figure 3). These abnormalities were exclusive to cFTCs in $55 \%$ of cases. Interestingly, $X$ gains were always whole-chromosome gains (Figure 2A). The content of these three distinctive chromosome regions is depicted in Table S1. 


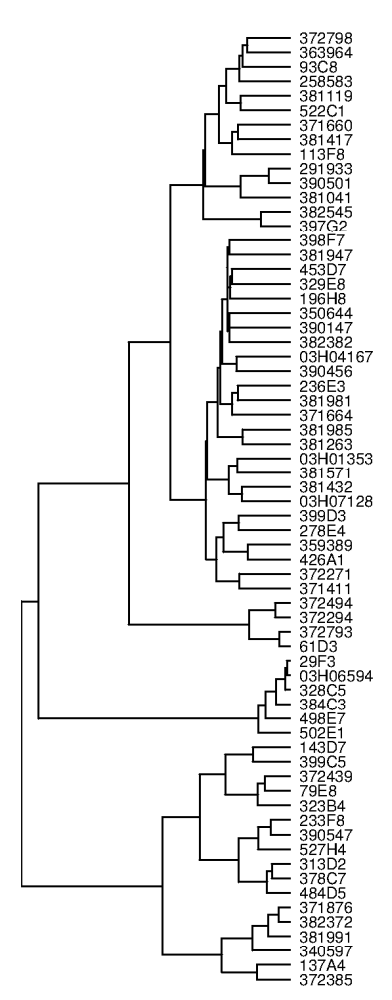

Distances: pearson QuantilieNorm: FALSE Agglomerative coet: 0.8574

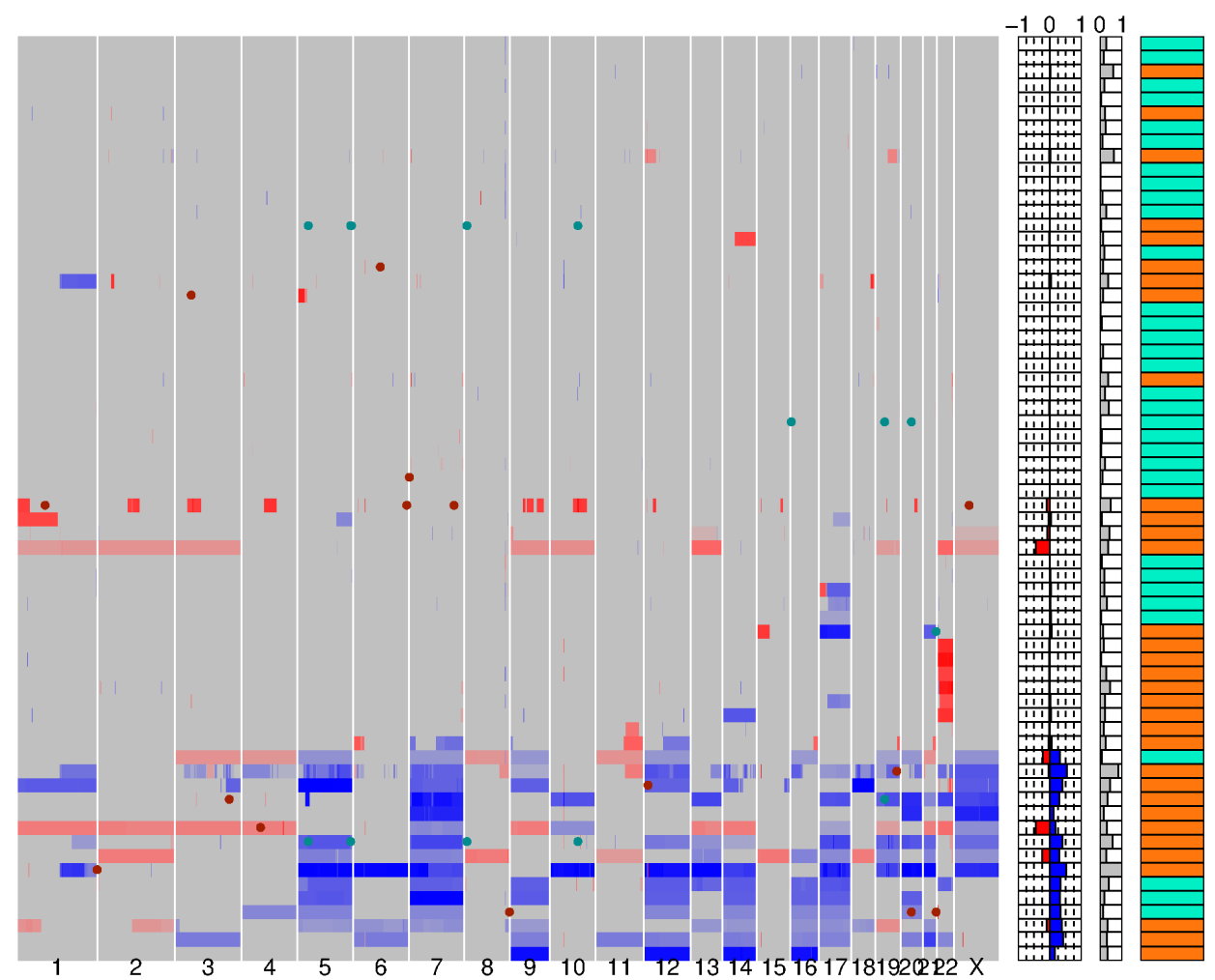

$\square$ Adenoma
Carcinoma

(A)

Figure 2. Cont. 

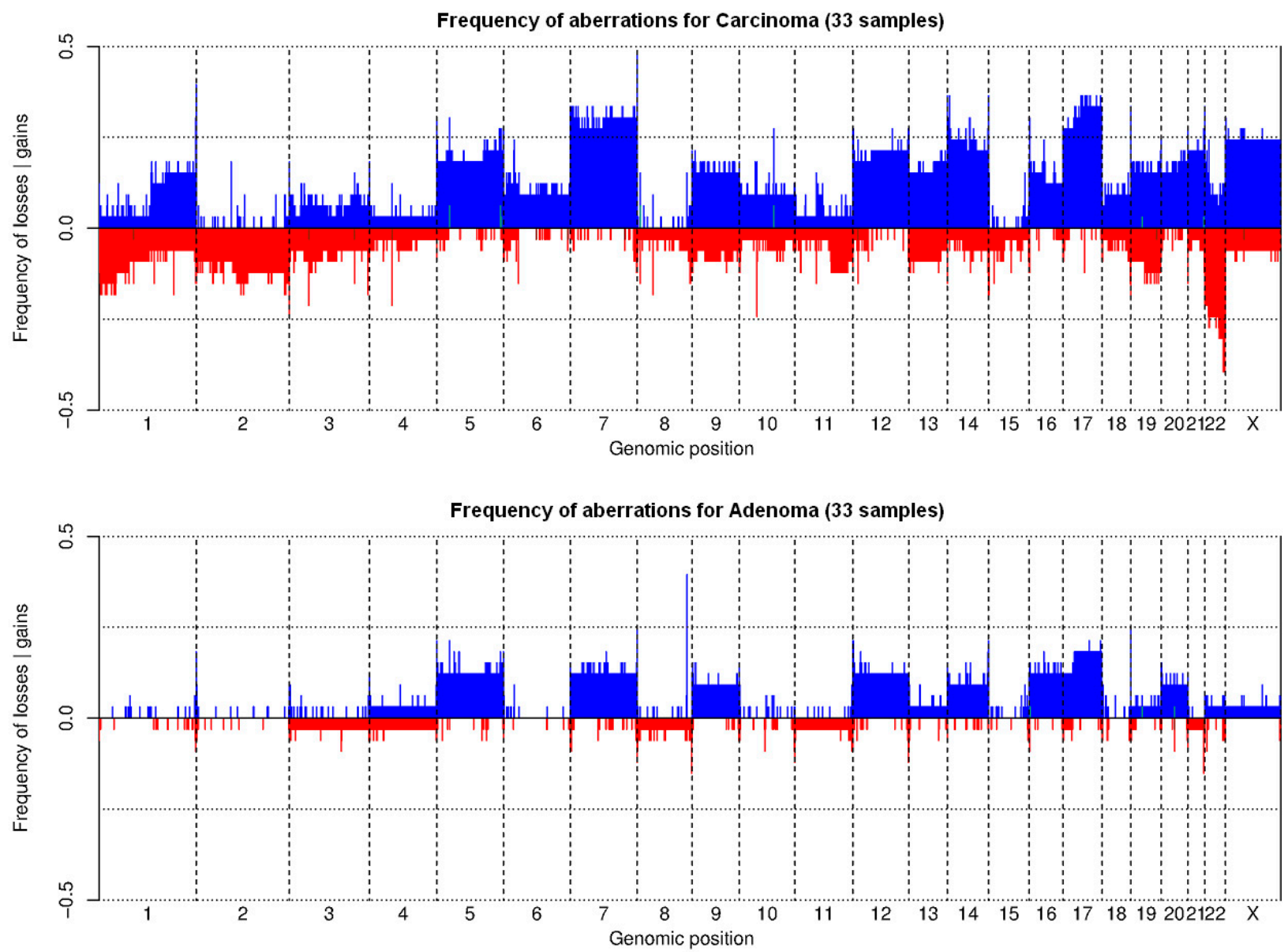

(B)

Figure 2. (A) Global heatmap of 66 clustered samples (training set: 33 cFTCs and 33 cFAs) using the Pearson distance and Ward's method. Each row represents a patient, and each column represents a chromosome. (B) Frequency plots of gains and losses for each chromosomal region of 66 samples. The red- and blue-colored bars correspond to the percentage of samples with losses or gains, respectively, at each indicated region. Abbreviations: Adenoma: classic follicular adenoma (cFA); Carcinoma: classic follicular thyroid carcinoma (cFTC). 


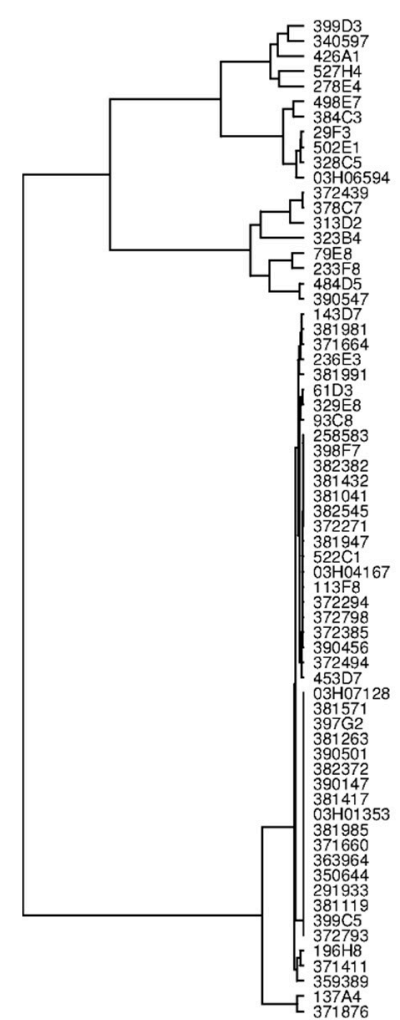

Distances: euclidean Method: ward QuantileNorm: FALSE Agglomerative coel: 0.9831
Amp (1.5)

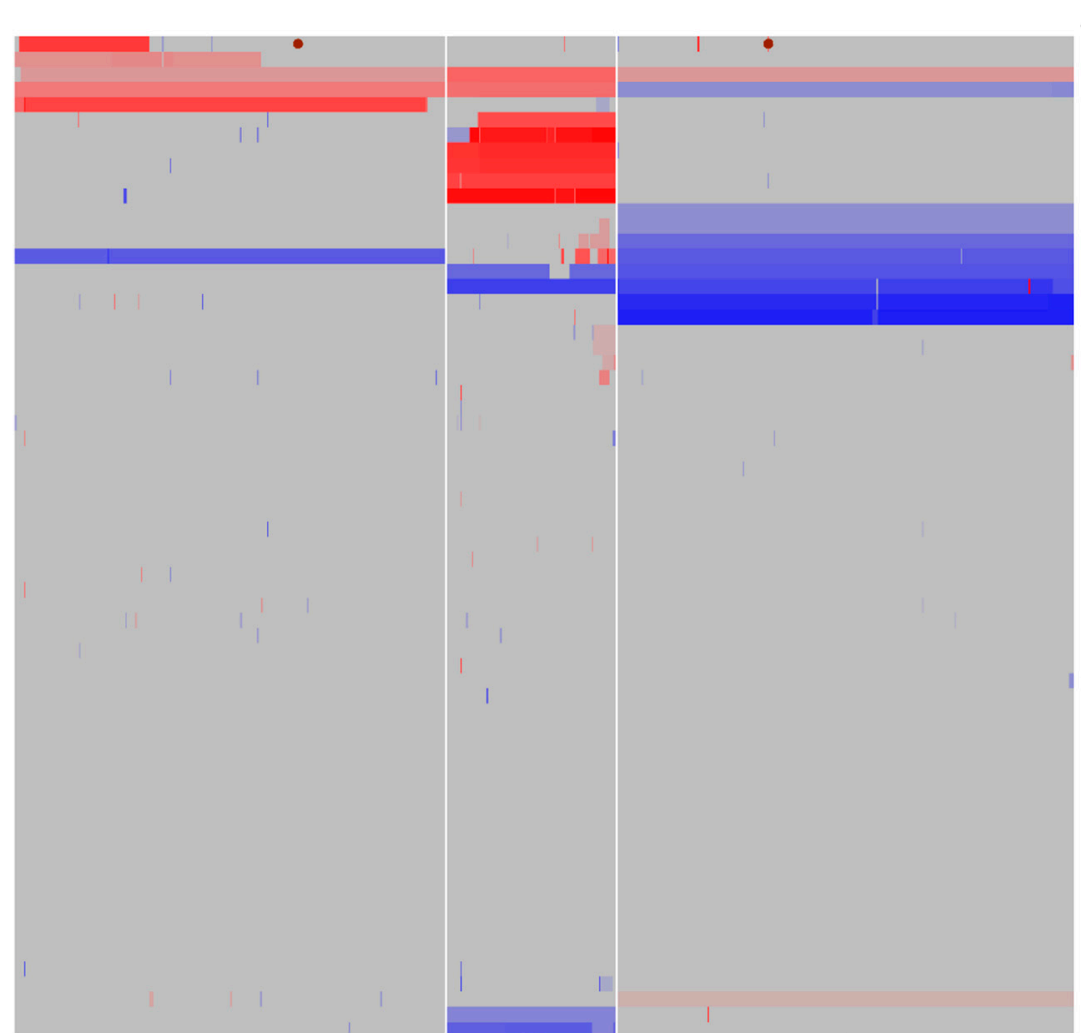

$1 p$

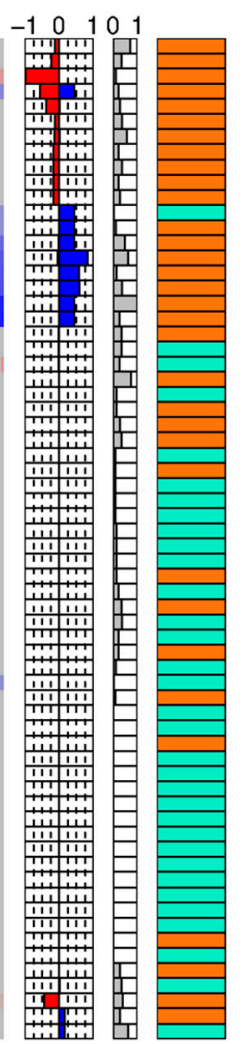

Adenoma

Carcinoma

Figure 3. Heatmap of the three chromosomes/chromosome arms that can be used to distinguish between cFA and cFTC tissues in the training set of 66 samples: chromosomes 1p, 22 and X (Euclidean distance, Ward's method). Abbreviations: Adenoma: classic follicular adenoma (cFA); Carcinoma: classic follicular thyroid carcinoma (cFTC). 


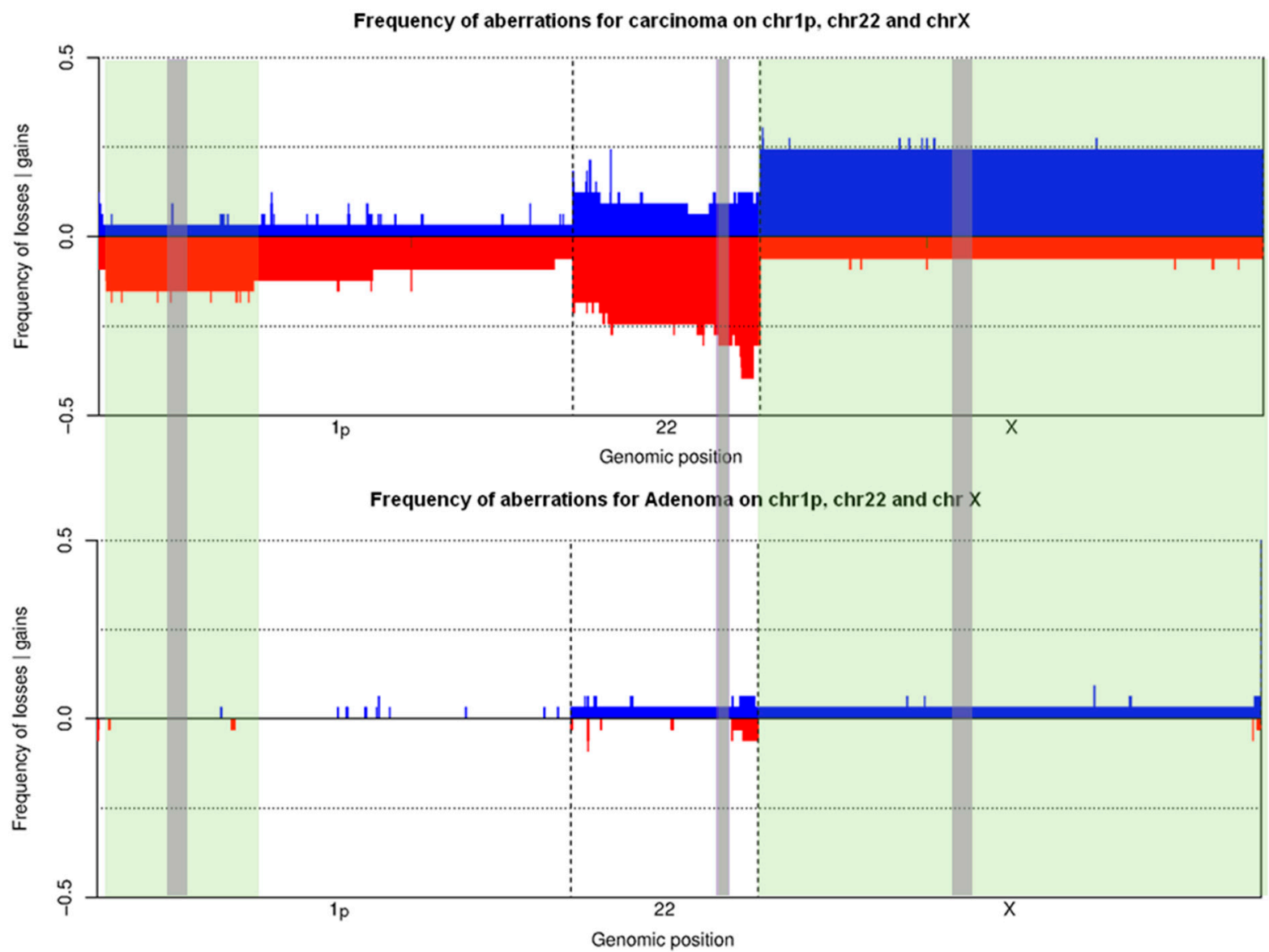

Figure 4. Localization of the minimum common regions of the chromosomal aberrations in cFA and cFTC as detected by aCGH (vertical green bands: loss of 1p36.33-1p35.1 and 22q13.2-22q13.31 and gain of X) and by commercially available DNA FISH probes specific to the 1p36.31, 22q13.3 loci and to the centromere of the $X$ chromosome (vertical gray bands). Abbreviations: aCGH: array comparative genomic hybridization; Adenoma: classic follicular adenoma (cFA); Carcinoma: classic follicular thyroid carcinoma (cFTC); DNA FISH: DNA fluorescent in situ hybridization. 
Commercially available DNA FISH probes targeting the three chromosomal regions for our Triple DNA FISH assay were selected as defined by aCGH and then used to study touch preparations obtained from frozen tissue of the training set consisting of an equal number $(n=33)$ of cFA and cFTC. Examples of such DNA FISH analyses are shown in Figure 5A-C. One 22q13.3 loss was identified by the Triple DNA FISH assay in a cFA case and not observed by aCGH. This was probably due to some level of tumor heterogeneity, that is, the tiny fraction of tumor cells carrying a particular genetic alteration was easily identified by DNA FISH but below the aCGH detection technical threshold. On the other hand, one case with $\mathrm{X}$ gain observed by aCGH was not detected by the Triple DNA FISH assay owing to the poor cellularity of the corresponding touch preparation.
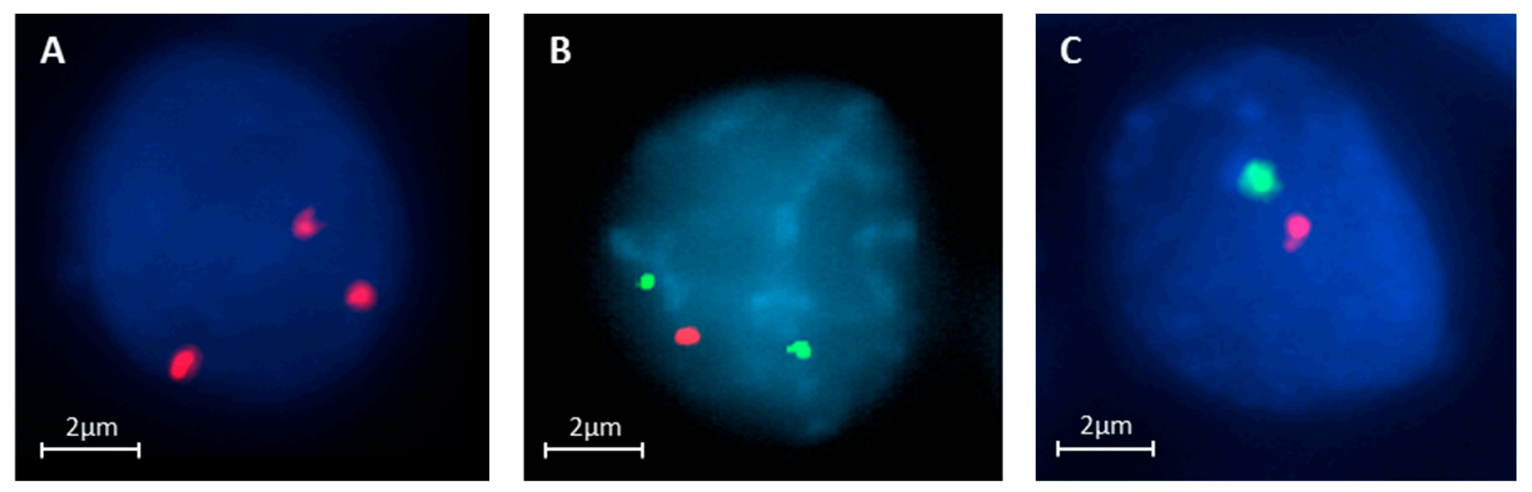

Figure 5. The Triple DNA FISH diagnostic assay illustrating the most common characteristic alterations detected in cFTC. (A) The three red signals show an X gain (female patient, Vysis CEP X/Y Abbott Laboratories, Abbott Park, IL, USA). (B) The two control green signals (1q25.3) and one red signal that is specific for 1p36.31 correspond to a loss of the 1p region (ZytoLight 1p36/1q25, ZytoVision, Bremerhaven, Germany). (C) One green signal (22q13.3) and one red signal (22q11.2) show a loss at 22q (LSI TUPLE 1/LSI ARSA, Abbott Laboratories). Abbreviation: cFTC: classic follicular thyroid carcinoma.

\subsection{Validation Set on Touch Preparations from Frozen Tissue}

Given these encouraging results, we then used the Triple DNA FISH assay to explore the molecular alterations in an independent validation set of 60 samples (60 pts, Figure 1). None of the adenomas carried any of the three tested abnormalities, whereas a total of 19 alterations (three cases of $1 \mathrm{p} 36.31$ loss; 12 cases of 22q13.3 loss; and four cases of $X$ gain) were found in 16 pts (47\%) with cFTC. In three cases, two alterations were found (1p36.31 loss systematically associated with 22q13.3 loss), and in contrast with the results of the training set, $\mathrm{X}$ gain was always found as the only abnormality in our validation set.

\subsection{Feasibility Set on Archived Already Stained Cytological Samples}

The Triple DNA FISH assay was also successfully carried out with the three commercially available probes in a series of 27 archived cytological specimens classified preoperatively as FN/SFN and representing the feasibility set (Table S2). Six (43\%) out of $14 \mathrm{cFTCs}$ but none of the $13 \mathrm{cFAs}$ were found to carry at least one of the three genetic alterations. Two cases corresponding to cFTCs showed loss of the 1p36.31 region, two had 22q13.3 deletions, two samples had X gain, and none had associated double or triple aberrations (Figure 6A,B). 


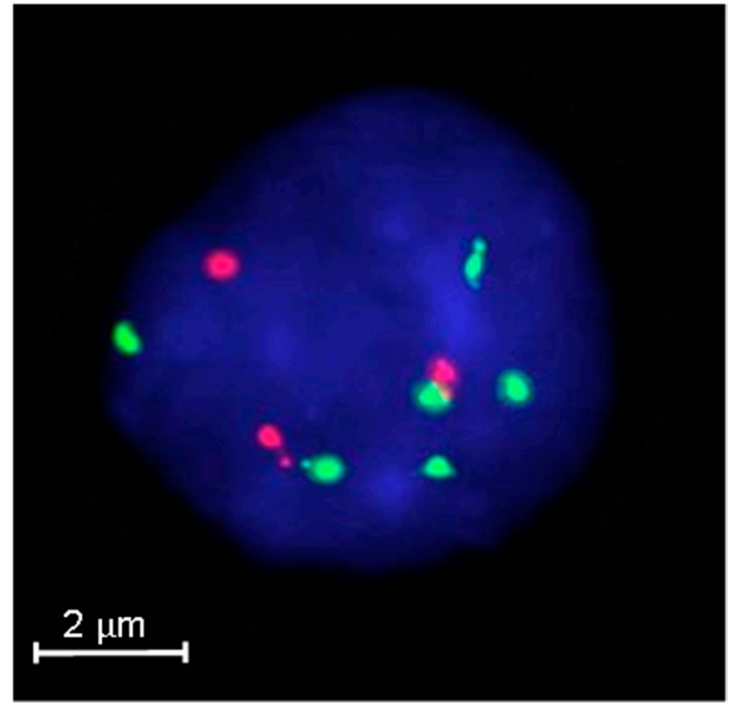

(A)

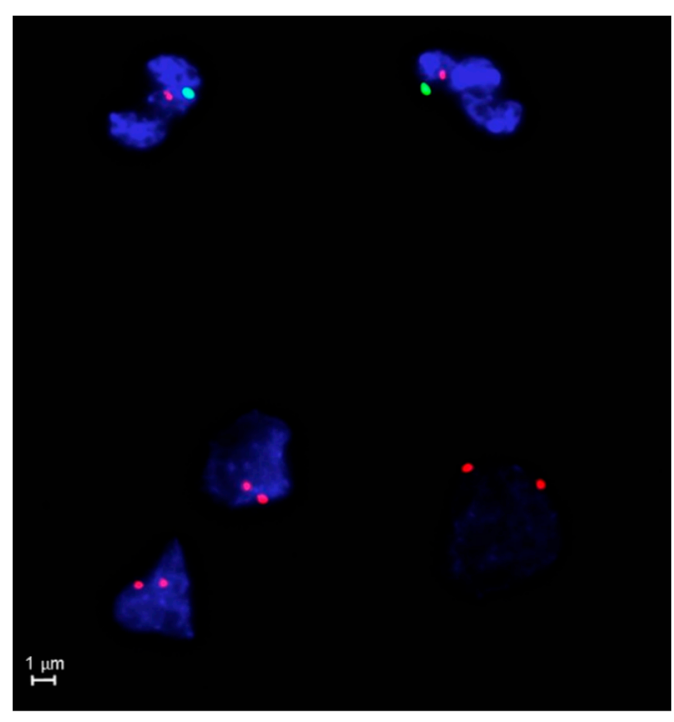

(B)

Figure 6. The Triple DNA FISH diagnostic assay on archived cytological samples of cFTC. (A) The six control green signals (1q25.3) and three red signals that are specific for 1p36.31 correspond to a loss of the 1p region (ZytoLight 1p36/1q25, ZytoVision, Bremerhaven, Germany). (B) The two red signals of the tumor cells show an $X$ (red) gain and $Y$ (green) loss next to normal granulocytes showing one red $(\mathrm{X})$ and one green $(\mathrm{Y})$ signal (male patient, Vysis CEP X/Y Abbott Laboratories, Abbott Park, IL, USA). Abbreviation: cFTC: classic follicular thyroid carcinoma.

\subsection{FISH Accuracy}

Accuracy characteristics of the Triple DNA FISH assay are detailed in Table S3 in the three individual sets (training: Table S3A, validation: Table S3B, and feasibility: Table S3C), and when they were associated (training plus validation: Table S3D, and training plus validation plus feasibility: Table S3E). As a whole (Table S3E), sensitivity and specificity were 56\% (95\% CI: 43-67) and 98\% (95\% CI: 91-100), respectively. Positive predictive values, negative predictive values and accuracy were respectively 98\% (95\% CI: 85-99), 64\% (95\% CI: 58-70) and 75\% (95\% CI: 66-82). Of note, these latter characteristics are dependent on disease prevalence. In our series disease prevalence was $55 \%$. Table S3 shows the same characteristics computed with a disease prevalence of $10 \%$, which may be closer to the real clinical setting.

\section{Discussion}

Our study identifies three distinctive chromosomal imbalances, namely, loss of 1p36.33-1p35.1, loss of 22q13.2-22q13.31 and gain of chromosome $X$ characteristic of half of thyroid cFTCs. Comparison of the aCGH and FISH results showed that when tissue was available for both techniques, alterations detected by aCGH were always confirmed by FISH (Table 2). We also show that these abnormalities are easily detectable by a Triple DNA FISH diagnostic assay on preoperative cytological specimens morphologically classified as FN/SFN. 
Table 2. Detection of the three genetic anomalies in classic follicular adenoma (cFA) and carcinoma (cFTC) in the training, validation and feasibility sets: comparison between aCGH and Triple DNA FISH assay.

\begin{tabular}{|c|c|c|c|c|c|c|c|c|}
\hline \multirow[b]{2}{*}{ Chromosome } & \multicolumn{2}{|c|}{ Training Set } & \multicolumn{2}{|c|}{ Validation Set } & \multicolumn{2}{|c|}{ Feasibility Set } & \multicolumn{2}{|c|}{ Total } \\
\hline & $\begin{array}{l}\text { Adenoma } \\
\text { aCGH (\%)/ } \\
\text { FISH (\%) }\end{array}$ & $\begin{array}{c}\text { Carcinoma } \\
\text { aCGH (\%)/ FISH } \\
(\%)\end{array}$ & $\begin{array}{l}\text { Adenoma } \\
\text { aCGH (\%)/ } \\
\text { FISH (\%) }\end{array}$ & $\begin{array}{c}\text { Carcinoma } \\
\text { aCGH (\%)/ } \\
\text { FISH (\%) }\end{array}$ & $\begin{array}{l}\text { Adenoma } \\
\text { aCGH (\%)/ } \\
\text { FISH (\%) }\end{array}$ & $\begin{array}{l}\text { Carcinoma } \\
\text { aCGH (\%)/ } \\
\text { FISH (\%) }\end{array}$ & $\begin{array}{c}\text { Adenoma } \\
\text { aCGH } \\
(\%) / \text { FISH (\%) }\end{array}$ & $\begin{array}{l}\text { Carcinoma } \\
\text { aCGH (\%)/ } \\
\text { FISH (\%) }\end{array}$ \\
\hline 1p36.31 loss & $0(0 \%) / 0(0 \%)$ & $5(15 \%) / 5(15 \%)$ & $-/ 0(0 \%)$ & $-/ 3(9 \%) \#$ & $-/ 0(0 \%)$ & $-/ 2(14 \%)$ & $0(0 \%) / 0(0 \%)$ & $5(6 \%) / 10(12 \%)$ \\
\hline 22q13.3 loss & $0(0 \%) / 1(3 \%)$ & $8(24 \%) / 8(24 \%)$ & $-/ 0(0 \%)$ & $-/ 12(35 \%) \#$ & $-/ 0(0 \%)$ & $-/ 2(14 \%)$ & $0(0 \%) / 1(1.4 \%)$ & $\begin{array}{c}8(9.9 \%) / 22 \\
(27 \%)\end{array}$ \\
\hline $\mathrm{X}$ gain & $1(3 \%) / 0(0 \%) *$ & $8(24 \%) / 8(24 \%) * *$ & $-/ 0(0 \%)$ & $-/ 4(12 \%) \#$ & $-/ 0(0 \%)$ & $-/ 2(14 \%)$ & $1(1.4 \%) / 0(0 \%)^{*}$ & $\begin{array}{c}8(9.9 \%) / 14 \\
(17.3 \%)^{* *}\end{array}$ \\
\hline Total & $\begin{array}{c}2 \text { alterations ( } 1 \\
\text { aCGH, } 1 \text { FISH) } \\
\text { in } 2 \text { patients } \\
(6 \%)\end{array}$ & $\begin{array}{l}22 \text { alterations }(21 \\
\text { aCGH, } 21 \text { FISH) }{ }^{* *} \\
\text { in } 18 \text { patients *** } \\
(55 \%)\end{array}$ & $\begin{array}{l}0 \text { alteration } \\
\text { (FISH) }(0 \%)\end{array}$ & $\begin{array}{l}19 \text { alterations } \\
(\mathrm{FISH}) \text { in } 16 \\
\text { patients }(47 \%)\end{array}$ & $\begin{array}{l}0 \text { alteration } \\
\text { (FISH) }(0 \%)\end{array}$ & $\begin{array}{c}6 \text { alterations } \\
(\mathrm{FISH}) \text { in } 6 \\
\text { patients }(43 \%)\end{array}$ & $\begin{array}{c}2 \text { alterations ( } 1 \\
\text { aCGH, } 1 \text { FISH) } \\
\text { in } 2 \text { patients } \\
(2.8 \%)\end{array}$ & $\begin{array}{c}47 \text { alterations } \\
(21 \text { aCGH, } 46 \\
\text { FISH) }{ }^{* *} \text { in } 40 \\
\text { patients }(49.4 \%)\end{array}$ \\
\hline
\end{tabular}


Among these three either isolated or associated chromosome imbalances, the loss of 22q13.3 was the most frequent $(30.3 \%)$, followed by the gain of chromosome $X(27.27 \%)$ and the loss of $1 \mathrm{p} 36.31$ $(18.18 \%)$ (Table S1). The observation of loss of 22q13.3 is in agreement with reports showing the frequent loss of chromosome 22 in cFTC [47-49]. Roque et al. [50] and Liu et al. [51] have suggested that a loss of 22q could represent a potential marker of "aggressive" adenomas. Loss of heterozygosity ( $\mathrm{LOH})$ and deletion at chromosome 22 have been reported in FVPTC [51-53], an entity we deliberately did not include in our study. The whole chromosome $X$ gain observed in both men and women in our series, which has been reported in one study [47], may suggest that it plays a significant role in cFTC. Interestingly, our study also shows that tumors with $X$ gain had highly aberrant genomes according to aCGH data in the training set (Figure 2A), even though DNA ploidy indices were 1.0 in five out of the six cases (the only DNA aneuploid case had a DNA index of 1.15). In the validation set where no aCGH analysis was performed, the four tumors with $X$ gain detected by DNA FISH were DNA diploid tumors in two cases and DNA multiploid tumors in two cases with DIs of 0.6 and 1.2 and 0.7 and 1.35. The loss of 1 p36.31 is in keeping with data reported first by Hemmer et al. [48,49] in 20\% of cFTCs and later by Roque et al. [50]. However, the minimal common region in Hemmer's studies was 1p22-21, in contrast to 1p36.33-1p35.1 in our series.

The global heatmap displayed in Figure 2A show significant differences and also some similarities between cFA and cFTC. It illustrates well the complexity [54] and diversity [55-57] of both entities, as well as the concept of genetic instability and of tumor genetic heterogeneity [58-60] in which the role of DNA ploidy is a matter of intense debate [61,62]. Differences are striking since the large majority $(88 \%)$ of $\mathrm{CFAs}$ did not exhibit somatic $\mathrm{SCNVs}$, while four $(12 \%)$ out of 33 did show complex abnormalities (Figure 2A), thereby making their possible premalignant potential questionable. By contrast, most cFTCs showed sCNVs, while 14 (42\%) out of $33 \operatorname{did}$ not (Figure 2A), a result that obviously deserves further investigation. Genetic instability is reflected in our DNA flow cytometric and aCGH data: $22(42 \%)$ out of 52 cFTCs and $22(37 \%)$ out of 59 cFAs exhibit DNA aneuploid cell fractions and chromosomal imbalances. Both are detectable in cFTCs and cFAs and more frequent $(58 \%)$ in the former (19 of 33) than in the latter (12\%: 4 of 33) as shown in Figure 2A. These data are in keeping with previous reports $[22,47,48,50,51,63-67]$ and with earlier studies using cytogenetics [68] and conventional CGH $[22,47,48,50,51,67]$ showing that imbalances mainly correspond to whole chromosome gains of chromosome 7 and losses of chromosomes 8, 11, 17 and 18 [50,64,69], respectively; however, losses of chromosome arms more frequently concerned $3 p, 11 q$ and $13 q$, with the loss of 22q being mainly observed in widely invasive cFTCs [48,49]. Similarly, the deletions of the regions harboring known tumor suppressor genes such as VHL (3p25-26), TP53 (17p13) and PTEN (10q23) [69-73] and copy number gains of PIK3CA on 3q26.32 [74] are mainly affected. Similarities concerning genetic endoreplication were noted in nine $(15 \%)$ out of 59 cFAs and in nine $(17 \%)$ out of 52 cFTCs, and DNA haploidy was found only in three (6\%) out of 52 cFTCs. Widespread LOH arising from haploidization [30] and of near-haploid chromosomal content has been reported in a large fraction of HCCs, including their metastases [29]. In addition to its widespread physiological role in development and tissue homeostasis across a large range of organisms, endoreplication and polyploidization are known to occur in various neoplasms [75]. Their relevance to genome instability and reversion from polyploidy to diploidy or aneuploidy have been described and may explain some aspects of tumorigenesis through dysregulation of various pathways [76], including EGFR/RAS/MAPK signaling [77]. Of note, it has been recently shown that whole-genome doubling buffers the impact of deleterious alterations [78] and that single-chromosomal gains can function as promoters and metastasis suppressors [79].

Differences and similarities between cFTC with cPTC and FVPTC have also been described. Differences concern patterns of upregulation and downregulation of gene [80-85], mRNA and miRNA [20,86-88] expression and chromosomal aberrations. First, cPTC and FVPTC have a low prevalence of chromosomal aberrations and the majority of tumors show no evidence of genetic instability $[22,52,89]$. Second, cPTC has a relatively quiet genome overall, as shown by conventional 
cytogenetics $[64,90,91]$, frequent (approximately $80 \%$ ) DNA diploidy detected by flow cytometry $[65,66]$, a low rate of $\mathrm{LOH}$ [63] and chromosomal imbalances detected in $40 \%$ of cases by CGH [47-50,92-96], aCGH [67,89,97], SNP array [51] or whole-exome sequencing [98]. Third, cPTC has one of the lowest overall somatic mutational burdens among all cancer types $[99,100]$. Similarities, however, are noticed when comparing our data and those derived from the large-scale next-generation approach performed by the TCGA consortium [20]. For example and in addition to the absence of chromosome arm-level alterations in $73 \%$ of cPTCs, the remaining tumors were also classified into three groups: a first one had single-arm imbalances consisting of cases (14\%) with an isolated $1 \mathrm{p}$ gain and a few other sCNVs enriched for PTC tall cell variants and $B R A F^{\mathrm{V} 600 \mathrm{E}}$ mutations; a second one $(10 \%)$ had an isolated $22 \mathrm{q}$ loss enrichment in FVPTC; and a third one comprised few cases (3\%) with a complex pattern of losses and gains involving multiple chromosome arms [20], in line with our set of cFTCs (39\%) exhibiting complex sCNVs (Figure 2A). Of note, the tendency of cFTCs to have no driver mutations or fusions parallels the existence of sCNVs, which may in turn suggest that $\mathrm{sCNV}$ by itself represent a driver event initiating the development of a subset of cFTCs.

We could not confirm loss of chromosome 9 in cFTC that contrasted with its gain in cFA [47] and did not find evidence for alterations of $P K C \varepsilon$ on $2 \mathrm{p} 21$, a candidate gene thought to be involved in thyroid tumorigenesis [101]. Furthermore, our findings are at variance with an aCGH study showing that: monosomy 21 appears to differentiate $100 \%$ of adenomas from carcinomas; trisomy 14 differentiates $100 \%$ of minimally invasive carcinomas from adenomas; and trisomy 10 identifies $100 \%$ of minimally invasive carcinomas from widely invasive carcinomas [102].

Our feasibility study further substantiated the application of the Triple DNA FISH assay on archived cytological material. For this purpose, we selected cytological slides with storage times varying between 1 month and 12 years, which opens the possibility for large retrospective studies. All 27 cases could be concluded, and the results found are in excellent agreement with our previous findings based on our training and validation sets. An evaluation algorithm depicting the main data interpretation steps of the Triple DNA FISH assay is shown in Figure 7. This algorithm could be applied in the cytomorphological differential diagnosis of FN/SFN sampled by FNAC. We contend that a panel including 1p36.31, 22q13.3 and centromere $X$ with 1q25.3, 22q11.2 and centromere $Y$ as controls represents a potential useful first-line adjunct of certain follicular tumors on initial cytological evaluation. Particular emphasis is advised in male patients with $X$ gain who show two $X$ signals and one $\mathrm{Y}$ signal in that the FISH result should be considered "trisomic". When the interpretation of the FISH results is unclear, DNA measurement by flow or static cytometry may be needed. However, in this case, other types of molecular tests could also be performed [103], or the patient could be considered a good candidate for conservative surgery, such as diagnostic lobectomy $[1,10]$.

The cytomorphological challenges encountered in Bethesda categories III and IV have indeed prompted scientists to develop preoperative genomic panels adapted to cytological samples obtained by FNAC, the so-called "rule-in" and "rule-out" tests [104]. The aim is to prevent the patient from repeating FNAC following an AUS/FLUS diagnosis or performing a diagnostic lobectomy with isthmusectomy in case of a diagnosis of FN/SFN $[1,10]$ by optimizing surgical management and reducing the avoidable treatment of benign nodules [3,104-106].

The ThyroSeq ${ }^{\circledR}$ v3 Genomic Classifier (CBL Path, Inc., Rye Brook, NY, USA and University of Pittsburgh Medical Center, Pittsburgh, PA, USA) is a "rule-in" method [107] based on targeted next-generation sequencing of DNA and RNA validated in a multicentric, prospective and blinded study [108]. The Afirma ${ }^{\circledR}$ Genomic Sequencing Classifier (GSC) (Veracyte, Inc., South San Francisco, CA, USA) is a next-generation "rule-out" method based on the previous Gene Expression Classifier validated first in a multicentric, prospective and blinded study [109] then with RNA-seq methodology [110]. The ThyGeNEXT/ThyraMIR ${ }^{\circledR}$ (Interspace Diagnostics, Inc., Parsippany, NJ, USA) is a combined method detecting gene mutations and fusions (ThyGeNEXT ${ }^{\circledR}$ ) and a complementary miRNA expression classifier (ThyraMIR ${ }^{\circledR}$ ) that has been clinically validated [111]. The Rosetta GX reveal ${ }^{\mathrm{TM}}$ Thyroid Classifier (Rosetta Genomics Philadelphia, PA, USA), no longer commercially available, was a validated 
method to evaluate the expression pattern of a series of miRNAs directly extracted from stained slides of preoperative FNAC [112]. The cost-effectiveness of the different molecular tests versus lobectomy is a matter of debate [113-115], and the main disadvantage of these methods is their cost, which makes them rarely used in Europe [116]. In addition, these tests were first mainly developed to identify cPTC and its variants and then to detect medullary thyroid carcinoma, Hürthle cell neoplasms and parathyroid tissue (Afirma ${ }^{\circledR}$, ThyroSeq ${ }^{\circledR}$, ThyGeNEXT/ThyraMIR ${ }^{\circledR}$ ) but not to specifically identify cFTC.

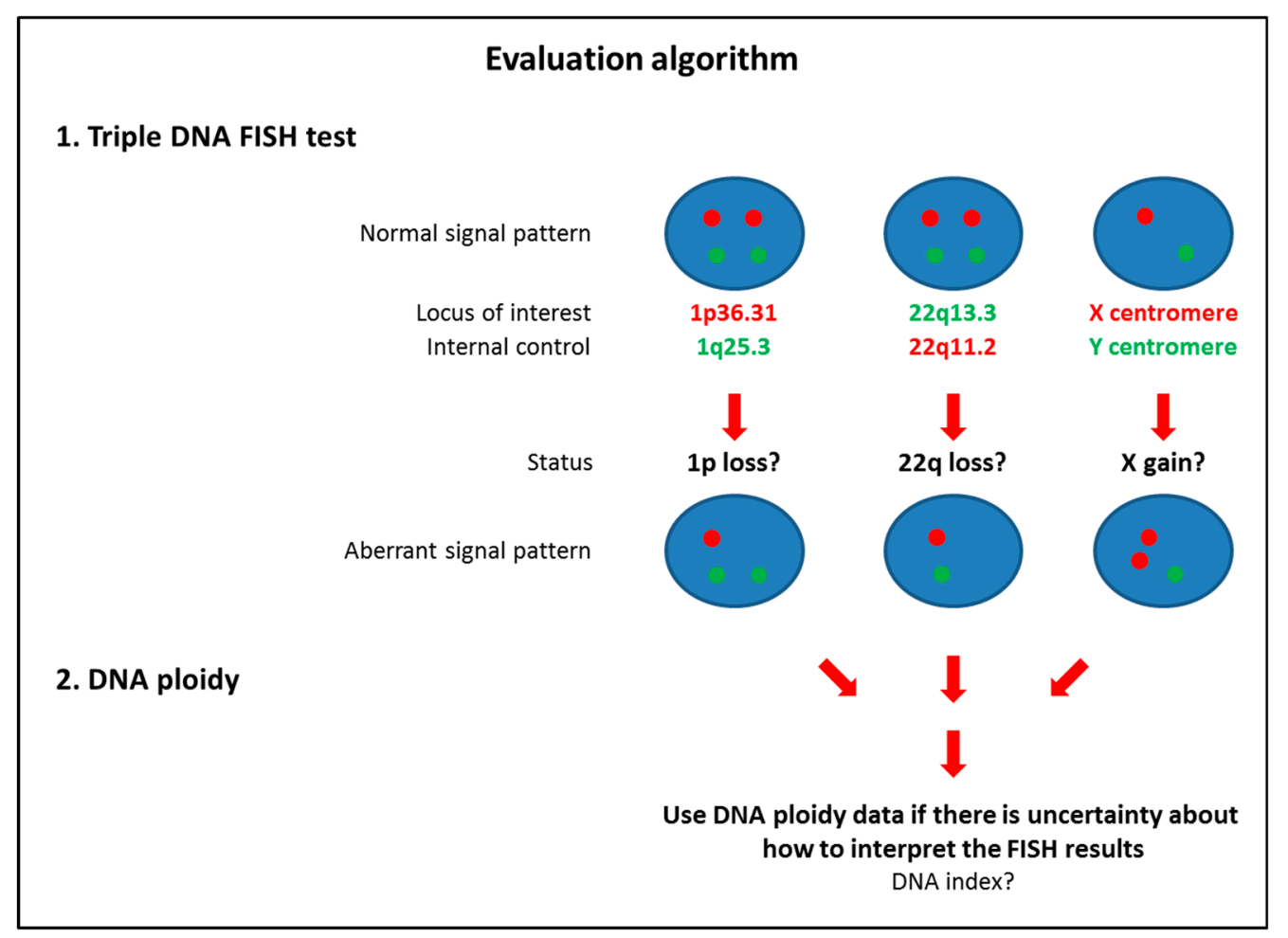

Figure 7. The evaluation algorithm of the Triple DNA FISH diagnostic assay depicts the main three normal and aberrant signal patterns observed in samples from $\mathrm{CFA}$ and $\mathrm{cFTC}$, respectively. Abbreviations: cFA: classic follicular adenoma; cFTC: classic follicular thyroid carcinoma; DNA FISH: DNA fluorescent in situ hybridization.

The advantages of our customized Triple DNA FISH diagnostic assay are multiple: it is a direct, rapid, and low-cost technique that is easy to perform in a routine laboratory equipped with basic fluorescence microscopy; it may be performed as the first-line approach on preoperatively stained slides with a cytological diagnosis of FN/SFN, obviating the need to perform an additional instant or delayed collection of material by FNAC for molecular testing; and it is a well-standardized diagnostic procedure that is adapted to the identification of cFTC and may be carried out on only a few cells, with the critical advantage of single-cell study.

There are several limitations in our study: its retrospective nature and the rate of sample exclusion in both the training $(14 \%)$ and validation $(12 \%)$ sets, which may introduce some bias in the statistical analysis, and the relatively small number of preoperative FNAC specimens $(n=27)$ tested. Although bicentric and showing a very high specificity (close to 100\%) at the expense of a low (50\%) sensitivity, our work obviously needs further prospective and multi-institutional validation and postvalidation studies in a routine clinical setting; the use of a relatively old oligonucleotide aCGH technology (Agilent 244K Whole Human Genome (G4411B)) is an intrinsic limit: the rapid evolution of current high-throughput technologies such as NGS may obviously and easily overcome this limit. However, given the size of the two region losses characterized, trying to more precisely define the subregions on chromosomes $1 p$ and $22 q$ and a gain of the entire chromosome $X$ may not be of actual interest; 
the presence of one case harboring a $B R A F^{600 \mathrm{E}}$ mutation is puzzling: this mutation is associated with CPTC in about half of the cases and in a higher percentage of the hobnail and tall cell variants, may be present in some FVPTCs, but should not be present in cFTCs, suggesting the possible misclassification of FVPTC (which was not observed after reviewing the corresponding sections again); the restrictive analysis of FN/SFN (Bethesda category IV) within the spectrum of indeterminate cases (gray zone) is an additional limitation of our study: according to TBSRTC [11,12], indeterminate cases comprise two other categories: AUS/FLUS (Bethesda category III) and SM (Bethesda category V). However, we deliberately focused on the FN/SFN (Bethesda IV) category because its pattern is well defined [117]; the AUS/FLUS category is still subject to significant interobserver variability [118-124] and may contain a significant number of FVPTCs [125]; and the SM category mainly corresponds to cPTC or variants of PTC [12].

In summary, we identified three distinctive chromosomal imbalances in a set of 153 pts with thyroid follicular lesions using aCGH and developed a Triple DNA FISH diagnostic assay. An evaluation algorithm to better distinguish between thyroid cFA and cFTC using our assay is presented in Figure 7 . This diagnostic assay detects structural abnormalities that were observed in approximately half of the cFTCs. It is easy to perform on archived cytological materials and its specificity higher than $98 \%$ might be comparable with $B R A F^{600 E}$ testing in cases of suspicion of PTC. In the context of challenges encountered in both ultrasonographic analyses [126-135] and indeterminate cytomorphology [118-124] as well as global financial restrictions, we believe our diagnostic assay merits further attention.

\section{Conclusions}

These data suggest that our triple DNA FISH diagnostic assay may detect $50 \%$ of cFTCs with a specificity higher than $98 \%$ and be useful as a low-cost adjunct to cytomorphology to help further classify follicular neoplasms on already routinely stained cytological specimens.

Supplementary Materials: The following are available online at http://www.mdpi.com/2072-6694/12/9/2529/s1, Table S1: Characteristics of the three distintive chromosome regions detected by aCGH altered in cFTC and frequency comparison between cFTC and cFA, Table S2: FISH on archived cytological materials of the thyroid, Table S3: Fish accuracy characteristics.

Author Contributions: Conceptualisation: P.V., B.C., P.H. and A.K.E.-N.; Methodology: Z.B., V.S., C.R., A.V., L.L., V.M., N.M. and V.L.; Software analysis: B.J., G.M. and P.D.; Resources: A.A.G., J.-M.B., A.K.E.-N. and M.S.; Original draft preparation: P.V., Z.B. and A.K.E.-N.; Review and editing: L.L., J.-M.B. and M.S.; Supervision: L.L., J.-Y.S. and P.V.; Project administration: V.M.; Funding acquisition: P.V. All authors have read and agreed to the published version of the manuscript.

Funding: This research was funded by French Institut National du Cancer (INCa), grant CYTHYR.

Conflicts of Interest: The authors have no conflicts of interest to declare.

\section{References}

1. Haugen, B.R.; Alexander, E.K.; Bible, K.C.; Doherty, G.M.; Mandel, S.J.; Nikiforov, Y.E.; Pacini, F.; Randolph, G.W.; Sawka, A.M.; Schlumberger, M.; et al. 2015 American thyroid association management guidelines for adult patients with thyroid nodules and differentiated thyroid cancer: The American thyroid association guidelines task force on thyroid nodules and differentiated thyroid cancer. Thyroid 2016, 26, 1-133. [CrossRef]

2. Gharib, H.; Papini, E.; Garber, J.R.; Duick, D.S.; Harrell, R.M.; Hegedus, L.; Paschke, R.; Valcavi, R.; Vitti, P. American association of clinical endocrinologists, American college of endocrinology, and associazione medici endocrinologi medical guidelines for clinical practice for the diagnosis and management of thyroid nodules-2016 update. Endocr. Pract. 2016, 22, 622-639. [CrossRef]

3. Paschke, R.; Cantara, S.; Crescenzi, A.; Jarzab, B.; Musholt, T.J.; Simoes, M.S. European thyroid association guidelines regarding thyroid nodule molecular fine-needle aspiration cytology diagnostics. Eur. Thyroid J. 2017, 6, 115-129. [CrossRef]

4. Schlumberger, M.J. Papillary and follicular thyroid carcinoma. N. Engl. J. Med. 1998, 338, 297-306. [CrossRef]

5. Siegel, R.L.; Miller, K.D.; Jemal, A. Cancer statistics, 2019. CA Cancer J. Clin. 2019, 69, 7-34. [CrossRef] 
6. Mazzaferri, E.L. Management of a solitary thyroid nodule. N. Engl. J. Med. 1993, 328, 553-559. [PubMed]

7. Hegedüs, L. Clinical practice. The thyroid nodule. N. Engl. J. Med. 2004, 351, 1764-1771. [CrossRef] [PubMed]

8. Burman, K.D.; Wartofsky, L. Clinical Practice. Thyroid nodules. N. Engl. J. Med. 2015, 373, $2347-2356$. [CrossRef] [PubMed]

9. Durante, C.; Grani, G.; Lamartina, L.; Filetti, S.; Mandel, S.J.; Cooper, D.S. The diagnosis and management of thyroid nodules: A review. JAMA 2018, 319, 914-924. [CrossRef]

10. Haddad, R.I.; Nasr, C.; Bischoff, L.; Busaidy, N.L.; Byrd, D.; Callender, G.; Dickson, P.; Duh, Q.Y.; Ehya, H.; Goldner, W.; et al. NCCN guidelines insights: Thyroid carcinoma, version 2.2018. J. Natl. Compr. Cancer Netw. 2018, 16, 1429-1440. [CrossRef] [PubMed]

11. Cibas, E.S.; Ali, S.Z. The Bethesda system for reporting thyroid cytopathology. Am. J. Clin. Pathol. 2009, 132, 658-665. [CrossRef]

12. Cibas, E.S.; Ali, S.Z. The 2017 Bethesda system for reporting thyroid cytopathology. Thyroid 2017, 27, 1341-1346. [CrossRef] [PubMed]

13. Bongiovanni, M.; Spitale, A.; Faquin, W.C.; Mazzucchelli, L.; Baloch, Z.W. The Bethesda system for reporting thyroid cytopathology: A meta-analysis. Acta Cytol. 2012, 56, 333-339. [CrossRef] [PubMed]

14. Nikiforov, Y.E.; Seethala, R.R.; Tallini, G.; Baloch, Z.W.; Basolo, F.; Thompson, L.D.R.; Barletta, J.A.; Wenig, B.M.; Al Ghuzlan, A.; Kakudo, K.; et al. Nomenclature revision for encapsulated follicular variant of papillary thyroid carcinoma: A paradigm shift to reduce overtreatment of indolent tumors. JAMA Oncol. 2016, 2, 1023-1029. [CrossRef] [PubMed]

15. Nikiforov, Y.E.; Baloch, Z.W.; Hodak, S.P.; Giordano, T.J.; Lloyd, R.V.; Seethala, R.R.; Wenig, B.M. Change in diagnostic criteria for noninvasive follicular thyroid neoplasm with papillarylike nuclear features. JAMA Oncol. 2018, 4, 1125-1126. [CrossRef]

16. World Health Organisation. Pathology and Genetics of Tumours of Endocrine Organs. In WHO Classification of Tumours of the Thyroid Gland, 3rd ed.; DeLellis, R.A., Llyod, R.V., Heitz, P.U., Eds.; International Agency for Research on Cancer (IARC) Press: Lyon, France, 2004; Volume 7.

17. Aschebrook-Kilfoy, B.; Schechter, R.B.; Shih, Y.C.; Kaplan, E.L.; Chiu, B.C.; Angelos, P.; Grogan, R.H. The clinical and economic burden of a sustained increase in thyroid cancer incidence. Cancer Epidemiol. Biomark. Prev. 2013, 22, 1252-1259. [CrossRef] [PubMed]

18. Nikiforov, Y.E. Role of molecular markers in thyroid nodule management: Then and now. Endocr. Pract. 2017, 23, 979-988. [CrossRef]

19. Yeh, M.W. The rise and fall of surgical aggressiveness for known or suspected differentiated thyroid cancer. Cancer Cytopathol. 2020. [CrossRef]

20. Cancer Genome Atlas Research Network. Integrated genomic characterization of papillary thyroid carcinoma. Cell 2014, 159, 676-690. [CrossRef]

21. Giordano, T.J. Follicular cell thyroid neoplasia: Insights from genomics and the cancer genome atlas research network. Curr. Opin. Oncol. 2016, 28, 1-4. [CrossRef]

22. Yoo, S.K.; Lee, S.; Kim, S.J.; Jee, H.G.; Kim, B.A.; Cho, H.; Song, Y.S.; Cho, S.W.; Won, J.K.; Shin, J.Y.; et al. Comprehensive analysis of the transcriptional and mutational landscape of follicular and papillary thyroid cancers. PLoS Genet. 2016, 12, e1006239. [CrossRef]

23. Acquaviva, G.; Visani, M.; Repaci, A.; Rhoden, K.J.; De Biase, D.; Pession, A.; Giovanni, T. Molecular pathology of thyroid tumours of follicular cells: A review of genetic alterations and their clinicopathological relevance. Histopathology 2018, 72, 6-31. [CrossRef] [PubMed]

24. Yakushina, V.D.; Lerner, L.V.; Lavrov, A.V. Gene fusions in thyroid cancer. Thyroid 2018, 28, $158-167$. [CrossRef]

25. Nikiforov, Y.E.; Ohori, N.P. Papillary Carcinoma. In Diagnostic Pathology and Molecular Genetics of the Thyroid: A Comprehensive Guide for Practicing Thyroid Pathology, 3rd ed.; Nikiforov, Y.E., Biddinger, P.W., Thompson, L.D.R., Eds.; Wolters Kluwer: Philadelphia, PA, USA, 2020; pp. 229-300.

26. Efanov, A.A.; Brenner, A.V.; Bogdanova, T.I.; Kelly, L.M.; Liu, P.; Little, M.P.; Wald, A.I.; Hatch, M.; Zurnadzy, L.Y.; Nikiforova, M.N.; et al. Investigation of the relationship between radiation dose and gene mutations and fusions in post-chernobyl thyroid cancer. J. Natl. Cancer Inst. 2018, 110, 371-378. [CrossRef] [PubMed] 
27. Nikiforov, Y.E. Thyroid Tumors: Classifications, and General Considerations. In Diagnostic Pathology and Molecular Genetics of the Thyroid: A Comprehensive Guide for Practicing Thyroid Pathology, 3rd ed.; Nikiforov, Y.E., Biddinger, P.W., Thompson, L.D.R., Eds.; Wolters Kluwer: Philadelphia, PA, USA, 2020; pp. 123-136.

28. Nikiforov, Y.E.; Biddinger, P.W.; Thompson, L.D.R. Diagnostic Pathology and Molecular Genetics of the Thyroid: A Comprehensive Guide for Practicing Thyroid Pathology, 3rd ed.; Wolters Kluwer: Philadelphia, PA, USA, 2020.

29. Gopal, R.K.; Kubler, K.; Calvo, S.E.; Polak, P.; Livitz, D.; Rosebrock, D.; Sadow, P.M.; Campbell, B.; Donovan, S.E.; Amin, S.; et al. Widespread chromosomal losses and mitochondrial DNA alterations as genetic drivers in Hurthle cell carcinoma. Cancer Cell 2018, 34, 242-255.e5. [CrossRef] [PubMed]

30. Ganly, I.; Makarov, V.; Deraje, S.; Dong, Y.; Reznik, E.; Seshan, V.; Nanjangud, G.; Eng, S.; Bose, P.; Kuo, F.; et al. Integrated genomic analysis of Hürthle cell cancer reveals oncogenic drivers, recurrent mitochondrial mutations, and unique chromosomal landscapes. Cancer Cell 2018, 34, 256-270.e5. [CrossRef]

31. Ganly, I.; McFadden, D.G. Short review: Genomic alterations in Hürthle cell carcinoma. Thyroid 2019, 29, 471-479. [CrossRef] [PubMed]

32. Grani, G.; Lamartina, L.; Durante, C.; Filetti, S.; Cooper, D.S. Follicular thyroid cancer and Hurthle cell carcinoma: Challenges in diagnosis, treatment, and clinical management. Lancet Diabetes Endocrinol. 2018, 6, 500-514. [CrossRef]

33. Gonzalez, J.L.; Wang, H.H.; Ducatman, B.S. Fine-needle aspiration of Hürthle cell lesions. A cytomorphologic approach to diagnosis. Am. J. Clin. Pathol. 1993, 100, 231-235. [CrossRef] [PubMed]

34. Renshaw, A.A. Hürthle cell carcinoma is a better gold standard than Hürthle cell neoplasm for fine-needle aspiration of the thyroid: Defining more consistent and specific cytologic criteria. Cancer 2002, 96, 261-266. [CrossRef]

35. Rossi, E.D.; Martini, M.; Straccia, P.; Raffaelli, M.; Pennacchia, I.; Marrucci, E.; Lombardi, C.P.; Pontecorvi, A.; Fadda, G. The cytologic category of oncocytic (Hurthle) cell neoplasm mostly includes low-risk lesions at histology: An institutional experience. Eur. J. Endocrinol. 2013, 169, 649-655. [CrossRef] [PubMed]

36. Auger, M. Hürthle cells in fine-needle aspirates of the thyroid: A review of their diagnostic criteria and significance. Cancer Cytopathol. 2014, 122, 241-249. [CrossRef] [PubMed]

37. Sobrinho-Simões, M.; Eloy, C.; Magalhães, J.; Lobo, C.; Amaro, T. Follicular thyroid carcinoma. Mod. Pathol. 2011, 24, S10-S18. [CrossRef] [PubMed]

38. Rosai, J.; DeLellis, R.A.; Carcangiu, M.L.; Frable, W.J.; Tallini, G. Tumors of the Thyroid and Parathyroid Glands, AFIP Atlas of Tumor Pathology; American Registry of Pathology: Silver Spring, MD, USA, 2015.

39. Ghossein, R. Update to the college of American pathologists reporting on thyroid carcinomas. Head Neck Pathol. 2009, 3, 86-93. [CrossRef] [PubMed]

40. Xu, B.; Ghossein, R.A. Crucial parameters in thyroid carcinoma reporting-Challenges, controversies and clinical implications. Histopathology 2018, 72, 32-39. [CrossRef] [PubMed]

41. World Health Organisation. Follicular Thyroid Carcinoma. In WHO Classification of Tumors of Endocrine Organs, 4th ed.; Lloyd, R.V., Osamura, R.Y., Klöppel, G., Rosai, J., Eds.; International Agency for Research on Cancer (IARC): Lyon, France, 2017; pp. 92-95.

42. Hiddemann, W.; Schumann, J.; Andreef, M.; Barlogie, B.; Herman, C.J.; Leif, R.C.; Mayall, B.H.; Murphy, R.F.; Sandberg, A.A. Convention on nomenclature for DNA cytometry. Committee on nomenclature, society for analytical cytology. Cancer Genet. Cytogenet. 1984, 13, 181-183. [CrossRef]

43. Olshen, A.B.; Venkatraman, E.S.; Lucito, R.; Wigler, M. Circular binary segmentation for the analysis of array-based DNA copy number data. Biostatistics 2004, 5, 557-572. [CrossRef]

44. Boichard, A.; Croux, L.; Al Ghuzlan, A.; Broutin, S.; Dupuy, C.; Leboulleux, S.; Schlumberger, M.; Bidart, J.M.; Lacroix, L. Somatic RAS mutations occur in a large proportion of sporadic RET-negative medullary thyroid carcinomas and extend to a previously unidentified exon. J. Clin. Endocrinol. Metab. 2012, 97, E2031-E2035. [CrossRef]

45. Lacroix, L.; Mian, C.; Barrier, T.; Talbot, M.; Caillou, B.; Schlumberger, M.; Bidart, J.M. PAX8 and peroxisome proliferator-activated receptor gamma 1 gene expression status in benign and malignant thyroid tissues. Eur. J. Endocrinol. 2004, 151, 367-374. [CrossRef]

46. Smida, J.; Salassidis, K.; Hieber, L.; Zitzelsberger, H.; Kellerer, A.M.; Demidchik, E.P.; Negele, T.; Spelsberg, F.; Lengfelder, E.; Werner, M.; et al. Distinct frequency of ret rearrangements in papillary thyroid carcinomas of children and adults from Belarus. Int. J. Cancer 1999, 80, 32-38. [CrossRef] 
47. Castro, P.; Eknaes, M.; Teixeira, M.R.; Danielsen, H.E.; Soares, P.; Lothe, R.A.; Sobrinho-Simoes, M. Adenomas and follicular carcinomas of the thyroid display two major patterns of chromosomal changes. J. Pathol. 2005, 206, 305-311. [CrossRef] [PubMed]

48. Hemmer, S.; Wasenius, V.M.; Knuutila, S.; Joensuu, H.; Franssila, K. Comparison of benign and malignant follicular thyroid tumours by comparative genomic hybridization. Br. J. Cancer 1998, 78, 1012-1017. [CrossRef] [PubMed]

49. Hemmer, S.; Wasenius, V.M.; Knuutila, S.; Franssila, K.; Joensuu, H. DNA copy number changes in thyroid carcinoma. Am. J. Pathol. 1999, 154, 1539-1547. [CrossRef]

50. Roque, L.; Rodrigues, R.; Pinto, A.; Moura-Nunes, V.; Soares, J. Chromosome imbalances in thyroid follicular neoplasms: A comparison between follicular adenomas and carcinomas. Genes Chromosom. Cancer 2003, 36, 292-302. [CrossRef] [PubMed]

51. Liu, Y.; Cope, L.; Sun, W.; Wang, Y.; Prasad, N.; Sangenario, L.; Talbot, K.; Somervell, H.; Westra, W.; Bishop, J.; et al. DNA copy number variations characterize benign and malignant thyroid tumors. J. Clin. Endocrinol. Metab. 2013, 98, E558-E566. [CrossRef]

52. Singh, B.; Lim, D.; Cigudosa, J.C.; Ghossein, R.; Shaha, A.R.; Poluri, A.; Wreesmann, V.B.; Tuttle, M.; Shah, J.P.; Rao, P.H. Screening for genetic aberrations in papillary thyroid cancer by using comparative genomic hybridization. Surgery 2000, 128, 888-893. [CrossRef]

53. Smit, J.W.; Van Zelderen-Bhola, S.; Merx, R.; De Leeuw, W.; Wessels, H.; Vink, R.; Morreau, H. A novel chromosomal translocation $\mathrm{t}(3 ; 5)(\mathrm{q} 12 ; \mathrm{p} 15.3)$ and loss of heterozygosity on chromosome 22 in a multifocal follicular variant of papillary thyroid carcinoma presenting with skin metastases. Clin. Endocrinol. (Oxf.) 2001, 55, 543-548. [CrossRef]

54. Swierniak, M.; Pfeifer, A.; Stokowy, T.; Rusinek, D.; Chekan, M.; Lange, D.; Krajewska, J.; Oczko-Wojciechowska, M.; Czarniecka, A.; Jarzab, M.; et al. Somatic mutation profiling of follicular thyroid cancer by next generation sequencing. Mol. Cell Endocrinol. 2016, 433, 130-137. [CrossRef]

55. Nikiforov, Y.E.; Nikiforova, M.N. Molecular genetics and diagnosis of thyroid cancer. Nat. Rev. Endocrinol. 2011, 7, 569-580. [CrossRef]

56. Pstrag, N.; Ziemnicka, K.; Bluyssen, H.; Wesoly, J. Thyroid cancers of follicular origin in a genomic light: In-depth overview of common and unique molecular marker candidates. Mol. Cancer 2018, 17, 116. [CrossRef]

57. Song, Y.S.; Park, Y.J. Genomic characterization of differentiated thyroid carcinoma. Endocrinol. Metab. 2019, 34, 1-10. [CrossRef] [PubMed]

58. Bakhoum, S.F.; Landau, D.A. Chromosomal instability as a driver of tumor heterogeneity and evolution. Cold Spring Harb. Perspect. Med. 2017, 7, a029611. [CrossRef] [PubMed]

59. McGranahan, N.; Swanton, C. Clonal heterogeneity and tumor evolution: Past, present, and the future. Cell 2017, 168, 613-628. [CrossRef] [PubMed]

60. Bakhoum, S.F.; Ngo, B.; Laughney, A.M.; Cavallo, J.A.; Murphy, C.J.; Ly, P.; Shah, P.; Sriram, R.K.; Watkins, T.B.K.; Taunk, N.K.; et al. Chromosomal instability drives metastasis through a cytosolic DNA response. Nature 2018, 553, 467-472. [CrossRef] [PubMed]

61. Sansregret, L.; Swanton, C. The role of aneuploidy in cancer evolution. Cold Spring Harb. Perspect. Med. 2017, 7, a028373. [CrossRef] [PubMed]

62. Taylor, A.M.; Shih, J.; Ha, G.; Gao, G.F.; Zhang, X.; Berger, A.C.; Schumacher, S.E.; Wang, C.; Hu, H.; Liu, J.; et al. Genomic and functional approaches to understanding cancer aneuploidy. Cancer Cell 2018, 33, 676-689.e3. [CrossRef] [PubMed]

63. Ward, L.S.; Brenta, G.; Medvedovic, M.; Fagin, J.A. Studies of allelic loss in thyroid tumors reveal major differences in chromosomal instability between papillary and follicular carcinomas. J. Clin. Endocrinol. Metab. 1998, 83, 525-530. [CrossRef]

64. Roque, L.; Clode, A.; Belge, G.; Pinto, A.; Bartnitzke, S.; Santos, J.R.; Thode, B.; Bullerdiek, J.; Castedo, S.; Soares, J. Follicular thyroid carcinoma: Chromosome analysis of 19 cases. Genes Chromosom. Cancer 1998, 21, 250-255. [CrossRef]

65. Greenebaum, E.; Koss, L.G.; Elequin, F.; Silver, C.E. The diagnostic value of flow cytometric DNA measurements in follicular tumors of the thyroid gland. Cancer 1985, 56, 2011-2018. [CrossRef] 
66. Schelfhout, L.J.; Cornelisse, C.J.; Goslings, B.M.; Hamming, J.F.; Kuipers-Dijkshoorn, N.J.; Van de Velde, C.J.; Fleuren, G.J. Frequency and degree of aneuploidy in benign and malignant thyroid neoplasms. Int. J. Cancer 1990, 45, 16-20. [CrossRef]

67. Jung, S.H.; Kim, M.S.; Jung, C.K.; Park, H.C.; Kim, S.Y.; Liu, J.; Bae, J.S.; Lee, S.H.; Kim, T.M.; Lee, S.H.; et al. Mutational burdens and evolutionary ages of thyroid follicular adenoma are comparable to those of follicular carcinoma. Oncotarget 2016, 7, 69638-69648. [CrossRef] [PubMed]

68. Wang, H.; Liu, H.; Min, S.; Shen, Y.; Li, W.; Chen, Y.; Wang, X. CDK16 overexpressed in non-small cell lung cancer and regulates cancer cell growth and apoptosis via a p27-dependent mechanism. Biomed. Pharmacother. 2018, 103, 399-405. [CrossRef] [PubMed]

69. Herrmann, M.A.; Hay, I.D.; Bartelt, D.H., Jr.; Ritland, S.R.; Dahl, R.J.; Grant, C.S.; Jenkins, R.B. Cytogenetic and molecular genetic studies of follicular and papillary thyroid cancers. J. Clin. Investig. 1991, 88, 1596-1604. [CrossRef] [PubMed]

70. Tung, W.S.; Shevlin, D.W.; Kaleem, Z.; Tribune, D.J.; Wells, S.A., Jr.; Goodfellow, P.J. Allelotype of follicular thyroid carcinomas reveals genetic instability consistent with frequent nondisjunctional chromosomal loss. Genes Chromosom. Cancer 1997, 19, 43-51. [CrossRef]

71. Segev, D.L.; Saji, M.; Phillips, G.S.; Westra, W.H.; Takiyama, Y.; Piantadosi, S.; Smallridge, R.C.; Nishiyama, R.H.; Udelsman, R.; Zeiger, M.A. Polymerase chain reaction-based microsatellite polymorphism analysis of follicular and Hürthle cell neoplasms of the thyroid. J. Clin. Endocrinol. Metab. 1998, 83, $2036-2042$. [CrossRef]

72. Kitamura, Y.; Shimizu, K.; Ito, K.; Tanaka, S.; Emi, M. Allelotyping of follicular thyroid carcinoma: Frequent allelic losses in chromosome arms 7q, 11p, and 22q. J. Clin. Endocrinol. Metab. 2001, 86, 4268-4272. [CrossRef]

73. Grebe, S.K.; McIver, B.; Hay, I.D.; Wu, P.S.; Maciel, L.M.; Drabkin, H.A.; Goellner, J.R.; Grant, C.S.; Jenkins, R.B.; Eberhardt, N.L. Frequent loss of heterozygosity on chromosomes 3p and 17p without VHL or p53 mutations suggests involvement of unidentified tumor suppressor genes in follicular thyroid carcinoma. J. Clin. Endocrinol. Metab. 1997, 82, 3684-3691. [CrossRef]

74. Wu, G.; Mambo, E.; Guo, Z.; Hu, S.; Huang, X.; Gollin, S.M.; Trink, B.; Ladenson, P.W.; Sidransky, D.; Xing, M. Uncommon mutation, but common amplifications, of the PIK3CA gene in thyroid tumors. J. Clin. Endocrinol. Metab. 2005, 90, 4688-4693. [CrossRef]

75. Storchova, Z.; Pellman, D. From polyploidy to aneuploidy, genome instability and cancer. Nat. Rev. Mol. Cell Biol. 2004, 5, 45-54. [CrossRef]

76. Fox, D.T.; Duronio, R.J. Endoreplication and polyploidy: Insights into development and disease. Development 2013, 140, 3-12. [CrossRef]

77. Shu, Z.; Row, S.; Deng, W.M. Endoreplication: The good, the bad, and the ugly. Trends Cell Biol. 2018, 28, 465-474. [CrossRef] [PubMed]

78. Lopez, S.; Lim, E.L.; Horswell, S.; Haase, K.; Huebner, A.; Dietzen, M.; Mourikis, T.P.; Watkins, T.B.K.; Rowan, A.; Dewhurst, S.M.; et al. Interplay between whole-genome doubling and the accumulation of deleterious alterations in cancer evolution. Nat. Genet. 2020, 52, 283-293. [CrossRef] [PubMed]

79. Vasudevan, A.; Baruah, P.S.; Smith, J.C.; Wang, Z.; Sayles, N.M.; Andrews, P.; Kendall, J.; Leu, J.; Chunduri, N.K.; Levy, D.; et al. Single-chromosomal gains can function as metastasis suppressors and promoters in colon cancer. Dev. Cell 2020, 52, 413-428.e6. [CrossRef] [PubMed]

80. Huang, Y.; Prasad, M.; Lemon, W.J.; Hampel, H.; Wright, F.A.; Kornacker, K.; LiVolsi, V.; Frankel, W.; Kloos, R.T.; Eng, C.; et al. Gene expression in papillary thyroid carcinoma reveals highly consistent profiles. Proc. Natl. Acad. Sci. USA 2001, 98, 15044-15049. [CrossRef] [PubMed]

81. Chevillard, S.; Ugolin, N.; Vielh, P.; Ory, K.; Levalois, C.; Elliott, D.; Clayman, G.L.; El-Naggar, A.K. Gene expression profiling of differentiated thyroid neoplasms: Diagnostic and clinical implications. Clin. Cancer Res. 2004, 10, 6586-6597. [CrossRef]

82. Frattini, M.; Ferrario, C.; Bressan, P.; Balestra, D.; De Cecco, L.; Mondellini, P.; Bongarzone, I.; Collini, P.; Gariboldi, M.; Pilotti, S.; et al. Alternative mutations of BRAF, RET and NTRK1 are associated with similar but distinct gene expression patterns in papillary thyroid cancer. Oncogene 2004, 23, 7436-7440. [CrossRef]

83. Giordano, T.J.; Kuick, R.; Thomas, D.G.; Misek, D.E.; Vinco, M.; Sanders, D.; Zhu, Z.; Ciampi, R.; Roh, M.; Shedden, K.; et al. Molecular classification of papillary thyroid carcinoma: Distinct BRAF, RAS, and RET/PTC mutation-specific gene expression profiles discovered by DNA microarray analysis. Oncogene 2005, 24, 6646-6656. [CrossRef] 
84. Vasko, V.; Espinosa, A.V.; Scouten, W.; He, H.; Auer, H.; Liyanarachchi, S.; Larin, A.; Savchenko, V.; Francis, G.L.; De la Chapelle, A.; et al. Gene expression and functional evidence of epithelial-to-mesenchymal transition in papillary thyroid carcinoma invasion. Proc. Natl. Acad. Sci. USA 2007, 104, 2803-2808. [CrossRef]

85. Knauf, J.A.; Sartor, M.A.; Medvedovic, M.; Lundsmith, E.; Ryder, M.; Salzano, M.; Nikiforov, Y.E.; Giordano, T.J.; Ghossein, R.A.; Fagin, J.A. Progression of BRAF-induced thyroid cancer is associated with epithelial-mesenchymal transition requiring concomitant MAP kinase and TGF $\beta$ signaling. Oncogene 2011, 30, 3153-3162. [CrossRef]

86. He, H.; Jazdzewski, K.; Li, W.; Liyanarachchi, S.; Nagy, R.; Volinia, S.; Calin, G.A.; Liu, C.G.; Franssila, K.; Suster, S.; et al. The role of microRNA genes in papillary thyroid carcinoma. Proc. Natl. Acad. Sci. USA 2005, 102, 19075-19080. [CrossRef]

87. Pallante, P.; Visone, R.; Ferracin, M.; Ferraro, A.; Berlingieri, M.T.; Troncone, G.; Chiappetta, G.; Liu, C.G.; Santoro, M.; Negrini, M.; et al. MicroRNA deregulation in human thyroid papillary carcinomas. Endocr. Relat. Cancer 2006, 13, 497-508. [CrossRef] [PubMed]

88. Nikiforova, M.N.; Tseng, G.C.; Steward, D.; Diorio, D.; Nikiforov, Y.E. MicroRNA expression profiling of thyroid tumors: Biological significance and diagnostic utility. J. Clin. Endocrinol. Metab. 2008, 93, 1600-1608. [CrossRef]

89. Finn, S.; Smyth, P.; O’Regan, E.; Cahill, S.; Toner, M.; Timon, C.; Flavin, R.; O'Leary, J.; Sheils, O. Low-level genomic instability is a feature of papillary thyroid carcinoma: An array comparative genomic hybridization study of laser capture microdissected papillary thyroid carcinoma tumors and clonal cell lines. Arch. Pathol. Lab. Med. 2007, 131, 65-73. [PubMed]

90. Roque, L.; Castedo, S.; Gomes, P.; Soares, P.; Clode, A.; Soares, J. Cytogenetic findings in 18 follicular thyroid adenomas. Cancer Genet. Cytogenet. 1993, 67, 1-6. [CrossRef]

91. Belge, G.; Roque, L.; Soares, J.; Bruckmann, S.; Thode, B.; Fonseca, E.; Clode, A.; Bartnitzke, S.; Castedo, S.; Bullerdiek, J. Cytogenetic investigations of 340 thyroid hyperplasias and adenomas revealing correlations between cytogenetic findings and histology. Cancer Genet. Cytogenet. 1998, 101, 42-48. [CrossRef]

92. Frisk, T.; Kytola, S.; Wallin, G.; Zedenius, J.; Larsson, C. Low frequency of numerical chromosomal aberrations in follicular thyroid tumors detected by comparative genomic hybridization. Genes Chromosom. Cancer 1999, 25, 349-353. [CrossRef]

93. Da Silva, L.; James, D.; Simpson, P.T.; Walker, D.; Vargas, A.C.; Jayanthan, J.; Lakhani, S.R.; McNicol, A.M. Tumor heterogeneity in a follicular carcinoma of thyroid: A study by comparative genomic hybridization. Endocr. Pathol. 2011, 22, 103-107. [CrossRef]

94. Kjellman, P.; Lagercrantz, S.; Höög, A.; Wallin, G.; Larsson, C.; Zedenius, J. Gain of 1q and loss of 9q21.3-q32 are associated with a less favorable prognosis in papillary thyroid carcinoma. Genes Chromosom. Cancer 2001, 32, 43-49. [CrossRef]

95. Wreesmann, V.B.; Sieczka, E.M.; Socci, N.D.; Hezel, M.; Belbin, T.J.; Childs, G.; Patel, S.G.; Patel, K.N.; Tallini, G.; Prystowsky, M.; et al. Genome-wide profiling of papillary thyroid cancer identifies MUC1 as an independent prognostic marker. Cancer Res. 2004, 64, 3780-3789. [CrossRef]

96. Rodrigues, R.; Roque, L.; Espadinha, C.; Pinto, A.; Domingues, R.; Dinis, J.; Catarino, A.; Pereira, T.; Leite, V. Comparative genomic hybridization, BRAF, RAS, RET, and oligo-array analysis in aneuploid papillary thyroid carcinomas. Oncol. Rep. 2007, 18, 917-926. [CrossRef]

97. Baldan, F.; Mio, C.; Allegri, L.; Passon, N.; Lepore, S.M.; Russo, D.; Damante, G. Evaluation of somatic genomic imbalances in thyroid carcinomas of follicular origin by CGH-based approaches. Minerva Endocrinol. 2018, 43, 285-293. [PubMed]

98. Nicolson, N.G.; Murtha, T.D.; Dong, W.; Paulsson, J.O.; Choi, J.; Barbieri, A.L.; Brown, T.C.; Kunstman, J.W.; Larsson, C.; Prasad, M.L.; et al. Comprehensive genetic analysis of follicular thyroid carcinoma predicts prognosis independent of histology. J. Clin. Endocrinol. Metab. 2018, 103, 2640-2650. [CrossRef] [PubMed]

99. Martincorena, I.; Campbell, P.J. Somatic mutation in cancer and normal cells. Science 2015, 349, 1483-1489. [CrossRef] [PubMed]

100. Giordano, T.J. Genomic hallmarks of thyroid neoplasia. Annu. Rev. Pathol. 2018, 13, 141-162. [CrossRef] [PubMed] 
101. Chen, X.; Knauf, J.A.; Gonsky, R.; Wang, M.; Lai, E.H.; Chissoe, S.; Fagin, J.A.; Korenberg, J.R. From amplification to gene in thyroid cancer: A high-resolution mapped bacterial-artificial-chromosome resource for cancer chromosome aberrations guides gene discovery after comparative genome hybridization. Am. J. Hum. Genet. 1998, 63, 625-637. [CrossRef]

102. Qureshi, A.A.; Collins, V.P.; Jani, P. Genomic differences in benign and malignant follicular thyroid tumours using 1-Mb array-comparative genomic hybridisation. Eur. Arch. Otorhinolaryngol. 2013, 270, 325-335. [CrossRef]

103. Rossi, E.D.; Pantanowitz, L.; Faquin, W.C. The role of molecular testing for the indeterminate thyroid FNA. Genes 2019, 10, 736. [CrossRef]

104. Eszlinger, M.; Lau, L.; Ghaznavi, S.; Symonds, C.; Chandarana, S.P.; Khalil, M.; Paschke, R. Molecular profiling of thyroid nodule fine-needle aspiration cytology. Nat. Rev. Endocrinol. 2017, 13, 415-424. [CrossRef]

105. Zhang, M.; Lin, O. Molecular testing of thyroid nodules: A review of current available tests for fine-needle aspiration specimens. Arch. Pathol. Lab. Med. 2016, 140, 1338-1344. [CrossRef]

106. Nishino, M.; Nikiforova, M. Update on molecular testing for cytologically indeterminate thyroid nodules. Arch. Pathol. Lab. Med. 2018, 142, 446-457. [CrossRef]

107. Nikiforova, M.N.; Mercurio, S.; Wald, A.I.; Barbi de Moura, M.; Callenberg, K.; Santana-Santos, L.; Gooding, W.E.; Yip, L.; Ferris, R.L.; Nikiforov, Y.E. Analytical performance of the ThyroSeq v3 genomic classifier for cancer diagnosis in thyroid nodules. Cancer 2018, 124, 1682-1690. [CrossRef] [PubMed]

108. Steward, D.L.; Carty, S.E.; Sippel, R.S.; Yang, S.P.; Sosa, J.A.; Sipos, J.A.; Figge, J.J.; Mandel, S.; Haugen, B.R.; Burman, K.D.; et al. Performance of a multigene genomic classifier in thyroid nodules with indeterminate cytology: A prospective blinded multicenter study. JAMA Oncol. 2019, 5, 204-212. [CrossRef] [PubMed]

109. Alexander, E.K.; Kennedy, G.C.; Baloch, Z.W.; Cibas, E.S.; Chudova, D.; Diggans, J.; Friedman, L.; Kloos, R.T.; LiVolsi, V.A.; Mandel, S.J.; et al. Preoperative diagnosis of benign thyroid nodules with indeterminate cytology. N. Engl. J. Med. 2012, 367, 705-715. [CrossRef] [PubMed]

110. Patel, K.N.; Angell, T.E.; Babiarz, J.; Barth, N.M.; Blevins, T.; Duh, Q.Y.; Ghossein, R.A.; Harrell, R.M.; Huang, J.; Kennedy, G.C.; et al. Performance of a genomic sequencing classifier for the preoperative diagnosis of cytologically indeterminate thyroid nodules. JAMA Surg. 2018, 153, 817-824. [CrossRef]

111. Labourier, E.; Shifrin, A.; Busseniers, A.E.; Lupo, M.A.; Manganelli, M.L.; Andruss, B.; Wylie, D.; Beaudenon-Huibregtse, S. Molecular testing for miRNA, mRNA, and DNA on fine-needle aspiration improves the preoperative diagnosis of thyroid nodules with indeterminate cytology. J. Clin. Endocrinol. Metab. 2015, 100, 2743-2750. [CrossRef]

112. Benjamin, H.; Schnitzer-Perlman, T.; Shtabsky, A.; VandenBussche, C.J.; Ali, S.Z.; Kolar, Z.; Pagni, F.; Bar, D.; Meiri, E. Analytical validity of a microRNA-based assay for diagnosing indeterminate thyroid FNA smears from routinely prepared cytology slides. Cancer Cytopathol. 2016, 124, 711-721. [CrossRef]

113. Vargas-Salas, S.; Martinez, J.R.; Urra, S.; Dominguez, J.M.; Mena, N.; Uslar, T.; Lagos, M.; Henriquez, M.; Gonzalez, H.E. Genetic testing for indeterminate thyroid cytology: Review and meta-analysis. Endocr. Relat. Cancer 2018, 25, R163-R177. [CrossRef]

114. Balentine, C.J.; Vanness, D.J.; Schneider, D.F. Cost-effectiveness of lobectomy versus genetic testing (Afirma ${ }^{\circledR}$ ) for indeterminate thyroid nodules: Considering the costs of surveillance. Surgery 2018, 163, 88-96. [CrossRef]

115. Nicholson, K.J.; Roberts, M.S.; McCoy, K.L.; Carty, S.E.; Yip, L. Molecular testing versus diagnostic lobectomy in Bethesda III/IV thyroid nodules: A cost-effectiveness analysis. Thyroid 2019, 29, 1237-1243. [CrossRef]

116. Sciacchitano, S.; Lavra, L.; Ulivieri, A.; Magi, F.; De Francesco, G.P.; Bellotti, C.; Salehi, L.B.; Trovato, M.; Drago, C.; Bartolazzi, A. Comparative analysis of diagnostic performance, feasibility and cost of different test-methods for thyroid nodules with indeterminate cytology. Oncotarget 2017, 8, 49421-49442. [CrossRef]

117. Renshaw, A.A.; Wang, E.; Wilbur, D.; Hughes, J.H.; Haja, J.; Henry, M.R. Interobserver agreement on microfollicles in thyroid fine-needle aspirates. Arch. Pathol. Lab. Med. 2006, 130, 148-152. [PubMed]

118. Gerhard, R.; Da Cunha Santos, G. Inter- and intraobserver reproducibility of thyroid fine needle aspiration cytology: An analysis of discrepant cases. Cytopathology 2007, 18, 105-111. [CrossRef] [PubMed]

119. Ohori, N.P.; Schoedel, K.E. Variability in the atypia of undetermined significance/follicular lesion of undetermined significance diagnosis in the Bethesda system for reporting thyroid cytopathology: Sources and recommendations. Acta Cytol. 2011, 55, 492-498. [CrossRef] [PubMed] 
120. Kholová, I.; Ludvíková, M. Thyroid atypia of undetermined significance or follicular lesion of undetermined significance: An indispensable Bethesda 2010 diagnostic category or waste garbage? Acta Cytol. 2014, 58, 319-329. [CrossRef] [PubMed]

121. Renshaw, A.A. Subclassification of atypical cells of undetermined significance in direct smears of fine-needle aspirations of the thyroid: Distinct patterns and associated risk of malignancy. Cancer Cytopathol. 2011, 119, 322-327. [CrossRef]

122. Padmanabhan, V.; Marshall, C.B.; Akdas Barkan, G.; Ghofrani, M.; Laser, A.; Tolgay Ocal, I.; David Sturgis, C.; Souers, R.; Kurtycz, D.F. Reproducibility of atypia of undetermined significance/follicular lesion of undetermined significance category using the Bethesda system for reporting thyroid cytology when reviewing slides from different institutions: A study of interobserver variability among cytopathologists. Diagn. Cytopathol. 2017, 45, 399-405.

123. Rossi, E.D.; Bizzarro, T.; Martini, M.; Larocca, L.M.; Schmitt, F.; Vielh, P. Cytopathology of follicular cell nodules. Adv. Anat. Pathol. 2017, 24, 45-55. [CrossRef]

124. Bellevicine, C.; Sgariglia, R.; Migliatico, I.; Vigliar, E.; D’Anna, M.; Nacchio, M.A.; Serra, N.; Malapelle, U.; Bongiovanni, M.; Troncone, G. Different qualifiers of AUS/FLUS thyroid FNA have distinct BRAF, RAS, RET/PTC, and PAX8/PPARg alterations. Cancer Cytopathol. 2018, 126, 317-325. [CrossRef]

125. Fazeli, R.; VandenBussche, C.J.; Bishop, J.A.; Ali, S.Z. Cytological diagnosis of follicular variant of papillary thyroid carcinoma before and after the Bethesda system for reporting thyroid cytopathology. Acta Cytol. 2016, 60, 14-18. [CrossRef]

126. Grant, E.G.; Tessler, F.N.; Hoang, J.K.; Langer, J.E.; Beland, M.D.; Berland, L.L.; Cronan, J.J.; Desser, T.S.; Frates, M.C.; Hamper, U.M.; et al. Thyroid ultrasound reporting lexicon: White paper of the ACR thyroid imaging, reporting and data system (TIRADS) committee. J. Am. Coll. Radiol. 2015, 12, 1272-1279. [CrossRef]

127. Russ, G.; Bonnema, S.J.; Erdogan, M.F.; Durante, C.; Ngu, R.; Leenhardt, L. European thyroid association guidelines for ultrasound malignancy risk stratification of thyroid nodules in adults: The EU-TIRADS. Eur. Thyroid J. 2017, 6, 225-237. [CrossRef] [PubMed]

128. Tessler, F.N.; Middleton, W.D.; Grant, E.G. Thyroid imaging reporting and data system (TI-RADS): A user's guide. Radiology 2018, 287, 1082. [CrossRef] [PubMed]

129. Chaigneau, E.; Russ, G.; Royer, B.; Bigorgne, C.; Bienvenu-Perrard, M.; Rouxel, A.; Leenhardt, L.; Belin, L.; Buffet, C. TIRADS score is of limited clinical value for risk stratification of indeterminate cytological results. Eur. J. Endocrinol. 2018, 179, 13-20. [CrossRef] [PubMed]

130. Castellana, M.; Castellana, C.; Treglia, G.; Giorgino, F.; Giovanella, L.; Russ, G.; Trimboli, P. Performance of five ultrasound risk stratification systems in selecting thyroid nodules for FNA. J. Clin. Endocrinol. Metab. 2020, 105, dgz170. [CrossRef] [PubMed]

131. Persichetti, A.; Di Stasio, E.; Coccaro, C.; Graziano, F.; Bianchini, A.; Di Donna, V.; Corsello, S.; Valle, D.; Bizzarri, G.; Frasoldati, A.; et al. Inter- and intraobserver agreement in the assessment of thyroid nodule ultrasound features and classification systems: A blinded multicenter study. Thyroid 2020, 30, 237-242. [CrossRef]

132. Modi, L.; Sun, W.; Shafizadeh, N.; Negron, R.; Yee-Chang, M.; Zhou, F.; Simsir, A.; Sheth, S.; Brandler, T.C. Does a higher American college of radiology thyroid imaging reporting and data system (ACR TI-RADS) score forecast an increased risk of malignancy? A correlation study of ACR TI-RADS with FNA cytology in the evaluation of thyroid nodules. Cancer Cytopathol. 2020. [CrossRef]

133. Castellana, M.; Piccardo, A.; Virili, C.; Scappaticcio, L.; Grani, G.; Durante, C.; Giovanella, L.; Trimboli, P. Can ultrasound systems for risk stratification of thyroid nodules identify follicular carcinoma? Cancer Cytopathol. 2020, 128, 250-259. [CrossRef]

134. Alexander, A.A. US-based risk stratification "guidelines" for thyroid nodules: Quō Vādis? J. Clin. Ultrasound 2020, 48, 127-133. [CrossRef]

135. Li, X.; Zhang, S.; Zhang, Q.; Wei, X.; Pan, Y.; Zhao, J.; Xin, X.; Qin, C.; Wang, X.; Li, J.; et al. Diagnosis of thyroid cancer using deep convolutional neural network models applied to sonographic images: A retrospective, multicohort, diagnostic study. Lancet Oncol. 2019, 20, 193-201. [CrossRef]

(C) 2020 by the authors. Licensee MDPI, Basel, Switzerland. This article is an open access article distributed under the terms and conditions of the Creative Commons Attribution (CC BY) license (http://creativecommons.org/licenses/by/4.0/). 